\title{
Three Proposals for Regulating the Distribution of Home Equity
}

\author{
Ian Ayres and Joshua Mitts $\dagger$
}

The Consumer Financial Protection Bureau's recently-released "qualified mortgage" rules effectively discourage predatory lending but miss an equally important source of systemic risk: low-equity clustering. Specific "volatility-inducing" mortgage terms, when present in a substantial cluster of mortgage contracts, exacerbate macroeconomic risk by increasing the chance that the housing and lending markets will have to absorb a wave of simultaneous defaults after a downturn in housing prices. This Article shows that these terms became prevalent in a substantial proportion of residential mortgages in the years leading up to the home mortgage crisis. In contrast, during the earlier "amortization era" (when mortgagors were more likely to borrow at different times, with more substantial down payments, and more continual rates of amortization, without a need to refinance), an equally-sized negative shock to housing prices would likely produce less negative equity and confine it to a smaller set of borrowers. Instead of prohibiting the volatilityinducing terms, this Article proposes three policies to better assure a greater diversification in the distribution of equity: (a) a modified home-mortgage interest deduction; (b) a modified "qualified residential mortgages" standard; and most importantly, (c) direct macroprudential regulation through a "capand-trade" system of leverage licenses and through instituting varying degrees of "conforming mortgages" for Fannie Mae and Freddie Mac. Limiting the simultaneous clustering of negative equity mortgages could reproduce the structural advantages of the amortization era, when inevitable downturns disparately impacted homeowners with different levels of equity and could more easily be absorbed by the market.

Introduction

I. The Limited Legal Response to Low-Equity Clustering

A. Consumer Protection, Predatory Lending, and Qualified

Mortgages Under the Dodd-Frank Act.

B. Qualified Residential Mortgages and Minimum Down Payments ... 88

$\dagger \quad$ Ian Ayres is the William K. Townsend Professor \& Anne Urowsky Professorial Fellow in Law at Yale Law School. He can be reached at ian.ayres@yale.edu. Joshua Mitts is an Associate at Sullivan \& Cromwell LLP. The views in this paper are those of Mr. Mitts and not those of his employer. He can be reached at joshua.mitts@aya.yale.edu. 
II. The Economic Effect of Low-Equity Clustering....................................90

A. Existing Research on Low-Equity Clustering ................................ 92

B. An Original Empirical Study on Low-Equity Clustering .................. 98

1. Research Design ...............................................................98

2. Econometric Model and Regression Results....................... 100

3. Home Price Regressions ................................................. 102

4. Default Rate Regressions .................................................... 105

III. Reforms to Promote Greater Diversity in the Distribution of Home

Equity........................................................................................ 107

A. Current Policies Increase Low-Equity Clustering ........................ 108

1. The Mortgage Interest Tax Deduction ...................................... 108

2. Government-Insured Mortgages ........................................ 110

B. Reforming the Home Mortgage Interest Deduction ...................... 112

C. Reforming the Dodd-Frank Risk-Retention Proposal.................... 116

IV. Direct Macroprudential Regulation of the Distribution of Equity ........... 122

A. A System of Tradable Leverage Licenses ..................................... 122

1. Why Licensing? The Advantages of Tradable Permits............ 125

2. Toward a New Regulatory Regime....................................... 128

3. Setting the Size of the Caps and Defining the Jurisdictions .... 130

4. Transition and Enforcement................................................. 134

B. Varying Conforming Mortgages for Fannie Mae and Freddie

Mac ......................................................................................... 136

1. The Role of the GSEs in the U.S. Mortgage Market .............. 136

2. A New Paradigm of Variation in Conforming Mortgages....... 139

Conclusion.

Introduction

One lesson from the Great Recession is abundantly clear: the terms of other people's mortgages can affect our financial security. When other people finance their housing purchases with little or no down payment, it increases systemic risk in the housing market. But the legislative response to the crisis has largely focused on trying to correct consumer error ${ }^{1}$ and has left the external impacts of individual lending decisions unaddressed.

The Dodd-Frank Act instituted two regulatory regimes to discourage the risky mortgage lending that led to the housing crisis: "qualified mortgages" $(\mathrm{QM})$ and "qualified residential mortgages" (QRM). One of these regulatory responses to the crisis even found its way into the 2012 presidential elections. In the first presidential debate, Governor Romney claimed:

1. See discussion infra Section I.A. 
Dodd-Frank correctly says we need to have qualified mortgages, and if you give a mortgage that's not qualified, there are big penalties, except they didn't ever go on and define what a qualified mortgage was. It's been two years. We don't know what a qualified mortgage is yet. So banks are reluctant to make loans, mortgages. $^{2}$

Two of these claims were incorrect. There are not "big penalties" for originating non-QM loans. On January 10, 2013, the Consumer Financial Protection Bureau (CFPB)' released rules giving lenders a safe harbor of compliance with a statutory mandate to verify a borrower's ability-to-repay for qualified mortgages. ${ }^{3}$ But lenders can still offer non-qualified mortgages by performing the requisite verification. ${ }^{4}$ And the delay in promulgating the QM rules could not have kept banks from lending because the ability-to-pay mandate was suspended until the QM rules were promulgated. ${ }^{5}$

On the other hand, Dodd-Frank's "qualified residential mortgages" (QRM) rules do impose a penalty for noncompliance. Under a proposal by six federal agencies in April 2011, mortgage securitizers must retain 5\% of the credit risk of any mortgage with a down payment lower than $20 \%{ }^{6}$ While this and other requirements for a QRM loan-such as fully amortizing payments with no deferring principal or balloons, no negative amortization, and no debtto-income ratio greater than $28 \%{ }^{7}$ - effectively reduce predatory lending, a $20 \%$ minimum down payment imposes a harsh burden on borrowers who are creditworthy but lack the wealth to provide such a large amount of cash up front.

More fundamentally, the proposed QRM rules do not effectively address the systemic consequences of mortgage terms that, in aggregate, can exacerbate market volatility. There is nothing individually irrational about a borrower and lender agreeing that the borrower will borrow with a small down payment or opting for a large repayment balloon in the future. But when millions of borrowers make the same kind of bet, too many of these highly-leveraged loans

2. Suzy Khimm, How a Moderate Mitt Romney Says He'd Regulate Wall Street, WASH. POST: WONKBLOG (Oct. 4, 2012, 11:18 AM), http://www.washingtonpost.com/blogs/wonkblog/wp /2012/10/04/how-a-moderate-mitt-romney-would-regulate-wall-street.

3. Ability-to-Repay and Qualified Mortgage Standards under the Truth in Lending Act, 12 C.F.R. $\S 1026.43(\mathrm{e})(1)(\mathrm{i})(2013)$.

4. See 15 U.S.C. $\S 1639 \mathrm{c}(\mathrm{b})(1)$ (2012) ("Any creditor with respect to any residential mortgage loan, and any assignee of such loan subject to liability under this subchapter, may presume that the loan has met the requirements of subsection (a), if the loan is a qualified mortgage." (emphasis added)).

5. See id. $\$ 1639 \mathrm{c}(\mathrm{a})(1)$ ("In accordance with regulations prescribed by the Bureau, no creditor may make a residential mortgage loan unless the creditor makes a reasonable and good faith determination based on verified and documented information that, at the time the loan is consummated, the consumer has a reasonable ability to repay the loan ...." (emphasis added)).

2011).

6. See Credit Risk Retention Proposed Rules, 76 Fed. Reg. 24,090, 24,099 (Apr. 29,

III.C.

7. See id. at 24,125 . For an in-depth discussion of the QRM standard, see infra Section 
make our housing markets less stable. QM and QRM thus under- and overreach: they largely fail to address the negative externality that high-risk lending can have on the remainder of the economy, and when they try to do so-i.e., by requiring a $20 \%$ down payment-they strike with a heavy hand not narrowly tailored to the goal of reducing systemic risk.

A more effective regulatory solution begins by identifying the phenomenon of "low-equity clustering." In the not-so-distant past, borrowers were more likely to take out amortizing loans, which pay back principal and interest with relatively constant monthly payments. During this amortization era (which lasted roughly from the end of World War II until roughly the beginning of President Clinton's term), at any point in time, different homeowners would have varying degrees of equity built up in their houses. Older homeowners would tend to own a larger proportion of their homes. Younger families not as much. ${ }^{8}$ This diversity in the degree of accrued equity reduced market volatility because economic shocks causing housing prices to drop would drive underwater only a relatively small proportion of the most recent mortgages.

In contrast, the Great Recession shows the macroeconomic dangers of uniformly high leverage. When a substantial proportion of the population has less than $5 \%$ equity in their homes, a $15 \%$ drop in housing prices is likely to cause a massive wave of defaults-further depressing housing prices and prompting even more defaults. From the perspective of market stability, low down payment mortgages with deferred or even negative amortization of principal robbed our nation of the diverse equity cushion that it enjoyed in the past.

In this Article, we focus on four different types of mortgage terms that, when present in a substantial number of loans, make the housing and banking markets more vulnerable to negative impacts from downturns in housing prices. The four mortgage terms are: (1) high loan-to-value (LTV) ratios; (2) low or delayed rates of amortization (including, for example, interest only loans); (3) substantial balloon payment obligations; and (4) artificial interest rate increases (for example, when interest rates rise at the end of a teaser rate period).

The first two of these terms directly reduce the size of the equity cushion that will exist at any point in time during the mortgage repayment-either because the initial down payment is a lower percentage of the purchase price or because the subsequent monthly payments are structured to more slowly pay back the outstanding principal. Even homeowners who initially borrow with more traditional mortgages (larger down payments and amortizing over fifteen to thirty years) are dynamically susceptible to "equity stripping," in which the homeowner takes out subsequent loans that extract the value that is built up

8. See, e.g., U.S. Census Bureau, RESIDENTIAL VACANCIES AND HOMEOWNERSHIP IN THE FOURTH QUARTER 2013, at 8, http://www.census.gov/housing/hvs/files/currenthvspress.pdf (last visited Feb. 14, 2014) (showing increasing homeownership rate with age from 2007-13). 
through the amortized repayment of the loan principal or through capital appreciation of the underlying home. In the extreme case, repeated equity stripping can dynamically transform amortizing mortgages into what in effect are interest-only loans and even ratchet the outstanding principal toward any capital appreciation in the home value. The combined impact of lower down payments, lower amortization, and increased equity stripping when adopted by a substantial group of homeowners leads to a phenomenon that we call "lowequity clustering." Low-equity clustering can exacerbate the impact of normal housing price fluctuations by unleashing a simultaneous wave of defaults (that would not have occurred under more traditional amortization distributions) as a large segment of homeowners walk away from underwater mortgages.

The second two types of terms (balloons and artificial resets) increase the risk of default when refinancing markets dry up after an initial fall in housing prices. Traditional amortizing mortgages do not require homeowners to return to the lending market to refinance the original principal. But mortgages with balloon payments or payment resets (that outstrip homeowners' ability to pay) force just this kind of refinancing. After an initial negative shock to housing prices, prudent lenders may be unwilling to refinance the outstanding principal of a mortgage when there is negative equity in a home at the time of the refinancing.

Taken together, these four volatility-inducing loan terms (individually or in combination) can exacerbate defaults either by increasing the number of underwater mortgages or by undermining lenders' willingness to refinance underwater mortgages. A central claim of this Article is that when substantial segments of mortgagors include such terms in their mortgages, the housing and lending markets are exposed to more systemic risk, because normal downturns in housing prices will be magnified by the secondary wave of foreclosure-based supply offered to the market after a rash of defaults. To absorb this terminduced foreclosure supply, the market price will fall further (which can in turn cause subsequent term-induced defaults) than it would in a world with more traditional mortgage terms.

Surprisingly, the regulatory response to the housing crisis has done little to nothing to address the macroeconomic externalities of homeowners bunching at very low levels of equity. The Dodd-Frank Act has attempted to address this concern through the proposed exemption to risk retention rules for qualified residential mortgages, ${ }^{9}$ but there is still no federal law prohibiting interest-only mortgages with zero percent down. It is as if regulators are resigned to the idea that the amortization era is gone and there is nothing we can do about it, or believe that the primary role for regulation is paternalisticto protect individual home lenders from making ill-advised borrowing decisions.

9. See discussion infra Section III.C. 
We support the consumer protection agenda. But there are also feasible interventions to reduce the negative externalities caused by risk-inducing loan terms. In this Article, we propose that the government auction off a limited number of "leverage licenses," which lenders would need to obtain before originating loans with particular kinds of terms. The licenses would directly limit the degree of low-equity clustering. Instead of prohibiting low-equity loans, the leverage licensing scheme would limit the number of high-leverage loans so as to produce the kind of equity distribution that is more robust to the unavoidable fluctuations in housing prices. Our licensing approach has distinct advantages over a more traditional prohibitory model. First, from a libertarian perspective, licensing grants more contractual liberty. ${ }^{10}$ Second, from the perspective of macroeconomic stability, there is nothing wrong with a handful of contractors including low-equity terms (or balloons or resets) in their mortgages. The housing market can easily absorb the low-equity induced defaults of a few highly leveraged loans. The systemic problem arises only when substantial segments of loans include such terms.

The impulse to simply prohibit contractors from including the offending terms derives from a kind of reverse aggregation fallacy. The traditional aggregation fallacy stems from failing to consider whether the individual benefits of a behavior would persist if everyone adopted the behavior. Thus, for example, the individual benefits gained in standing at a football game are eliminated if everyone stands. But we commit the reverse aggregation fallacy when we fail to consider the comparatively small negative externalities that would accrue if only a few people adopt a behavior. The social ills stemming from mass clustering of low-equity loans do not imply that unclustered lowequity lending produces the same harms. In the mortgage setting the football analogy does not hold. Unlike the first football fans, who block others by standing, the first few borrowers with low-equity or low-amortization terms produce at most only imperceptible negative effects on others in the market. A system of limited licensing more narrowly tailors the restrictions of contractual freedom to the specific externality concerns. With traded licenses, the right to include the license terms will naturally flow to the contractors who value them most highly.

Indeed, traditional prohibitory regulation may perversely induce just the kinds of clustering that stability regulation should strive to eliminate. For example, regulation that simply prohibits originations with loan-to-value ratios of more than $95 \%$ may induce a large segment of borrowers to cluster just next to the $5 \%$ down payment requirement-leaving the system particularly vulnerable to downturns in housing prices of, say, 6-10\%. Traditional prohibitions may be particularly ill suited to the regulatory goal of inducing the

10. A libertarian commitment to freedom of contract does not preclude limitations on liberty in order to reduce social externalities. 
optimal macroeconomic distributions in contracting equilibria. Or put in terms of traditional contract theory, mandatory rules are well suited to inducing pooling equilibria, but can be less useful when the regulatory goal is to produce non-pooling equilibria in which different contractors opt for different contract terms.

In this Article, we propose three complementary reforms that could be used individually or together to reduce the problems of low-equity clustering. First, we suggest that the home equity deduction be limited to loans that are more likely to amortize over time and have no balloon payments or artificial interest rate resets. Second, we suggest reforms to the proposed QRM riskretention rules to give originating lenders better incentives to offer loans that would produce better distributions of risk. And lastly we propose direct macroprudential regulation of the distribution of home equity through (1) a system of tradable leverage licenses that would allow a limited number of loans at different equity ranges, and (2) a new paradigm of "conforming mortgages" for Fannie Mae and Freddie Mac.

Part I of this Article demonstrates that the legal response to the recent housing crisis fails to address low-equity clustering. Part II presents evidence establishing (1) the rising prevalence of particular mortgage terms and (2) the link between low-equity clustering and the downturn in housing prices during the recent crisis. Part III critiques existing policies that encourage low-equity clustering and suggests two reforms to promote greater diversification in the distribution of equity. Part IV proposes direct macroprudential regulation of the distribution of home equity through a system of tradable leverage licenses and reforms to the "conforming mortgage" system for Fannie Mae and Freddie Mac to increase stability in the housing market.

\section{The Limited Legal Response to Low-Equity Clustering}

\section{A. Consumer Protection, Predatory Lending, and Qualified Mortgages Under the Dodd-Frank Act}

The Dodd-Frank Act and the related regulatory responses to the housing and financial crisis of 2007-2009 fall short of comprehensively addressing a fundamentally important source of systemic risk to housing markets: the aggregate effect of the distribution of certain types of risky individual mortgage terms. In its report on the financial crisis, the Financial Crisis Inquiry Commission (FCIC) described the growth in the mid-2000s of high-risk mortgage terms that would later have a devastating effect on society:

Direct-mail solicitations flooded people's mailboxes. Dancing figures, depicting happy homeowners, boogied on computer monitors. Telephones began ringing off the hook with calls from loan officers offering the latest loan products: One percent loan! (But only for the first year.) No money down! (Leaving no equity 
if home prices fell.) No income documentation needed! (Mortgages soon dubbed "liar loans" by the industry itself.) Borrowers answered the call, many believing that with ever-rising prices, housing was the investment that couldn't lose. ${ }^{11}$

There is widespread consensus that mortgage terms such as these-e.g., "one percent for the first year" or "no money down"-played a substantial role in the causal chain leading to the meltdown in housing markets beginning in $2007 .{ }^{12}$

However, the regulatory response to the explosive growth of these terms has focused almost exclusively on consumer protection. The FCIC emphasized that borrowers "were misled by salespeople who came to their homes and persuaded them to sign loan documents on their kitchen tables. Some borrowers naively trusted mortgage brokers who earned more money placing them in risky loans than in safe ones." 13 When characterizing the growth of option "adjustable rate mortgages" (ARM) loans-which featured interest rate resets and negative amortization payment options-the FCIC quotes testimony that borrowers were "steered or defrauded into entering option ARMs with teaser rates or pick-a-pay loans forcing them to [pay] loans that they could never pay off." 14 When the FCIC discusses the role these mortgage terms played in leading to the housing crisis, the clear implication is that consumers did not realize the risk their loans entailed. ${ }^{15}$

It is no surprise, then, that the Dodd-Frank Act, and rules promulgated under the Act, have focused on protecting consumers from predatory lending. Dodd-Frank established a new section 129C of the Truth-in-Lending Act, which provides that "no creditor may make a residential mortgage loan unless the creditor makes a reasonable and good faith determination based on verified and documented information that, at the time the loan is consummated, the consumer has a reasonable ability to repay the loan."16 The statute expressly mandates that the creditor consider:

11. THE FINANCLAL CRISIS INQUIRY REPORT: FINAL REPORT OF THE NATIONAL COMMISSION ON THE CAUSES OF THE FINANCIAL AND ECONOMIC CRISIS IN THE UNITED STATES, FIN. CRISIS INQUIRY COMM'N 9 (2011), http://www.gpo.gov/fdsys/pkg/GPO-FCIC/pdf/GPO-FCIC.pdf.

12. See, e.g., id. at 105 .

13. Id. at 7 .

14. Id. at 109 (quoting The Financial Crisis at the Community Level-Sacramento, CA, FIN. CRISIS INQUIRY COMM'N 228 (Sept. 23, 2010) (statement of Mona Tawatao), http://fcic-static.law .stanford.edu/cdn_media/fcic-testimony/2010-0923-transcript.pdf). "Pick-a-pay" loans, also known as option adjustable-rate mortgages, permit making "a partial-interest payment that adds the unpaid interest to the loan's balance." Marshall Eckblad, Pick-a-Pay Loans: Worse than Subprime, WALL ST. J., July 14, 2009, http://online.wsj.com/article/SB124744382165530247.html.

15. See FIN. CRISIS INQUIRY COMM'N, supra note 11, at 6-7 ("Soon there were a multitude of different kinds of mortgages available on the market, confounding consumers who didn't examine the fine print, baffling conscientious borrowers who tried to puzzle out their implications, and opening the door for those who wanted in on the action.").

16. 15 U.S.C. $\S 1639 \mathrm{c}(\mathrm{a})(1)(2012)$. 
[T] he consumer's credit history, current income, expected income the consumer is reasonably assured of receiving, current obligations, debt-to-income ratio or the residual income the consumer will have after paying non-mortgage debt and mortgage-related obligations, employment status, and other financial resources other than the consumer's equity in the dwelling or real property that secures repayment of the loan. A creditor shall determine the ability of the consumer to repay using a payment schedule that fully amortizes the loan over the term of the loan. ${ }^{17}$

The statute also requires that creditors verify a borrower's income to prevent fraud $^{18}$ and take into account nonstandard terms when determining ability to repay. ${ }^{19}$ For example, creditors must "take into consideration any balance increase that may accrue from any negative amortization provision" 20 and "use the payment amount required to amortize the loan by its final maturity" for interest-only loans. ${ }^{21}$ Section $129 \mathrm{C}$ also encourages creditors to refinance borrowers into higher quality loans-e.g., with a lower interest rate, fully amortizing payment schedule, and no balloon payment-by exempting such refinancing loans from income verification. ${ }^{22}$

But the most important provision in section $129 \mathrm{C}$ is the presumption of compliance with the ability-to-repay requirement for "qualified mortgages.",23 Under the statute, a mortgage must contain the following elements to be a "qualified mortgage": (1) fully amortizing with no deferring principal repayment; ${ }^{24}$ (2) no balloon payment; ${ }^{25}$ (3) verification of the borrower's income; ${ }^{26}$ (4) for fixed-rate loans, underwriting based on a fully amortizing payment schedule including all taxes, insurance, and assessments; ${ }^{27}$ (5) for ARM loans, underwriting based on the maximum interest rate over the first five years with the same payment schedule requirements for fixed-rate loans; ${ }^{28}(6)$ compliance with any maximum debt-to-income ratios set by the CFPB, which has rulemaking authority for qualified mortgages; ${ }^{29}$ (7) no more than $3 \%$ in points and fees; ${ }^{30}$ and (8) maximum length of thirty years. ${ }^{31}$

\footnotetext{
17. $I d . \S 1639 \mathrm{c}(\mathrm{a})(3)$.

18. Id. $\$ 1639 \mathrm{c}(\mathrm{a})(4)$.

19. Id. $\S 1639 \mathrm{c}(\mathrm{a})(6)$.

20. Id. $\S 1639 \mathrm{c}(\mathrm{a})(6)(\mathrm{C})$.

21. Id. $\$ 1639 \mathrm{c}(\mathrm{a})(6)(\mathrm{B})$.

22. Id. $\S 1639 \mathrm{c}(\mathrm{a})(5)$.
}

23. Id. $\$ 1639 \mathrm{c}(\mathrm{b})(1)$ ("Any creditor with respect to any residential mortgage loan, and any assignee of such loan subject to liability under this subchapter, may presume that the loan has met the requirements of subsection (a), if the loan is a qualified mortgage.").
24. Id. $\$ 1639 \mathrm{c}(\mathrm{b})(2)(\mathrm{A})(\mathrm{i})$.
25. Id. $\$ 1639 \mathrm{c}(\mathrm{b})(2)(\mathrm{A})(\mathrm{ii})$.
26. Id. $\S 1639 \mathrm{c}(\mathrm{b})(2)(\mathrm{A})(\mathrm{iii})$.
27. $I d . \S 1639 \mathrm{c}(\mathrm{b})(2)(\mathrm{A})(\mathrm{iv})$.
28. Id. $\S 1639 \mathrm{c}(\mathrm{b})(2)(\mathrm{A})(\mathrm{v})$.
29. Id. $\S 1639 \mathrm{c}(\mathrm{b})(2)(\mathrm{A})(\mathrm{vi})$.
30. $I d . \S 1639 \mathrm{c}(\mathrm{b})(2)(\mathrm{A})(\mathrm{vii})$. 
On January 10, 2013, the CFPB promulgated final rules implementing the ability-to-repay standard and qualified mortgage exemption. ${ }^{32}$ These rules clarified several ambiguities in the statutory definition. Specifically, the CFPB provided for a safe harbor-a presumption of compliance with the ability-torepay standard-for qualified mortgages that are not "higher-priced" as defined by the Federal Reserve Board's 2008 truth-in-lending rule. ${ }^{33}$ The bureau also used its authority under the statute to define a maximum total debt-to-income ratio of $43 \%$ for qualified mortgages. ${ }^{34}$ Finally, the CFPB provided for a second, temporary category of qualified mortgages, which will enjoy the benefit of the safe harbor based on somewhat looser criteria if they comply with the underwriting criteria of the government-sponsored enterprises (GSEs) (while they remain under federal conservatorship), the Department of Housing and Urban Development, the Department of Veterans Affairs, or the Department of Agriculture or Rural Housing Service. ${ }^{35}$

The qualified mortgage standard as a safe-harbor proxy for a borrower's ability to repay is predominantly driven by a regulatory consumer protection concern. We support this type of soft paternalism. ${ }^{36}$ It is reasonable to protect borrowers from making ill-advised loans.

But inadequate consumer protection should not be the government's only concern. Macroprudential considerations militate in favor of regulating terms of mortgage contracts that produce negative externalities in the form of exacerbated systemic market risk. Individual lending decisions can have negative externalities when they increase the risk of synchronized default. A vast body of economic research has found a strong connection between negative equity-so-called "underwater" borrowers-and default. Theoretically, it is not in a rational homeowner's interest to make payments on a mortgage with a principal balance greater than the value of the house. ${ }^{37}$ In a

31. Id. $\S 1639 \mathrm{c}(\mathrm{b})(2)(\mathrm{A})($ viii). There is also a provision for reverse mortgages, see id. $\S$ $1639 \mathrm{c}(\mathrm{b})(2)(\mathrm{A})(\mathrm{ix})$.

32. Ability-to-Repay and Qualified Mortgage Standards Under the Truth in Lending Act, 12 C.F.R. $\S 1026(2013)$.

33. Id. $\S 1026.43(\mathrm{e})(1)(\mathrm{i})$.

34. Id. $\S 1026.43(\mathrm{e})(2)(\mathrm{vi})$.

35. Id. § $1026.43(\mathrm{e})(4)$.

36. Indeed, one of us recently advocated requiring lenders "who use non-default terms to undertake consumer surveys to establish that typical borrowers in real-world contexts understand the non-default terms of the mortgage." Ian Ayres, Regulating Opt-Out: An Economic Theory of Altering Rules, 121 YALE L.J. 2032, 2102 (2012).

37. This is known as the "put option" theory of mortgage default, which was first articulated in Chester Foster \& Robert Van Order, An Option-Based Model of Mortgage Default, 3 HOUSING FIN. REV. 351 (1984). The model was later developed through literature described and evaluated in Kerry D. Vandell, How Ruthless is Mortgage Default? A Review and Synthesis of the Evidence, 6 J. HousING RES. 245 (1995); and Roberto G. Quercia \& Michael A. Stegman, Residential Mortgage Default: $A$ Review of the Literature, 3 J. HousING RES. 341 (1992). See also Yongheng Deng et al., Mortgage Terminations, Heterogeneity and the Exercise of Mortgage Options, 68 ECONOMETRICA 275, 275 (2000) (synthesizing the put option literature and concluding that the model "in its most straightforward version, does a good job of explaining default and prepayment, but it is not enough by 
world of zero transaction costs, he or she should simply default on the loan and obtain a lower mortgage on an equivalent substitute house that now costs less. ${ }^{38}$ Of course, the real world is not free of transaction costs, ${ }^{39}$ and subsequent empirical studies have shown that "liquidity shocks" such as losing a job, divorce, or unplanned medical expenses are usually necessary for negative equity to lead to default. ${ }^{40}$ But more recent empirical studies demonstrate that negative equity remains a primary determinant of default. ${ }^{41}$

The consumer protection approach reflected in the ability-to-repay mandate and the qualified mortgage safe harbor does not address the contribution that low-equity loans make to systemic risk as a result of these

itself'); Anthony Pennington-Cross \& Giang Ho, The Termination of Subprime Hybrid and Fixed-Rate Mortgages, 3 REAL ESTATE ECON. 399 (2010) (applying option theory to the subprime mortgage termination).

38. Theoretically, at least, a true substitute house should cost the same as the borrower's current house, which has now dropped in value.

39. See James B. Kau et al., Default Probabilities for Mortgages, 35 J. URB. ECON. 278 (1994). Kau et al. argue that it is essential to take into account the loss of the possibility of future prepayment of the mortgage when the termination option is exercised. See id. at 282. In their view, transaction costs have no effect on the exercise of the termination option. But see John M. Quigley \& Robert Van Order, Explicit Tests of Contingent Claims Models of Mortgage Default, $11 \mathrm{~J}$. REAL ESTATE FIN. \& ECON. 99, 112 (1995) ("[E]mpirical analysis suggests that a zero transaction cost model is not consistent with the data.").

40. See Wayne R. Archer et al., The Effect of Income and Collateral Constraints on Residential Mortgage Terminations, 26 REGIONAL SCI. \& URB. ECON. 235, 237 (1996) (finding that "the termination behavior of households that are income- or collateral-constrained differs markedly from unconstrained households"); Christopher L. Foote et al., Negative Equity and Foreclosure: Theory and Evidence, 64 J. URB. ECON. 234, 245 (2008) ("The default decision involves weighing the payments on the mortgage against the income, imputed or actual, that accrues from retaining ownership of the house.").

41. See Ronel Elul et al., What "Triggers" Mortgage Default?, 100 AM. ECON. REV. 490 (2010) (finding support for both the negative equity and illiquidity theories of default); Laurie S. Goodman et al., Negative Equity Trumps Unemployment in Predicting Defaults, 19 J. FIXED INCOME 67 (2010) (concluding that while negative equity is a stronger predictor of default than unemployment, unemployment can function as a trigger of default when there is high negative equity); Patrick Bajari et al., An Empirical Model of Subprime Mortgage Default from 2000 to 2007 (Nat'1 Bureau of Econ. Research, Working Paper No. 14625, 2010), http://www.econ.umn.edu/ bajari/research/subprime.pdf (concluding that negative equity is an important determinant of default but insufficient on its own); Kristopher Gerardi et al., Subprime Outcomes: Risky Mortgages, Homeownership Experiences, and Foreclosures 1 (Fed. Reserve Bank of Bos. Working Paper No. 07-15, 2007), $\mathrm{http} / / / \mathrm{www}$.bos.frb.org/economic/wp/wp2007/wp0715.pdf (conducting an empirical study of subprime mortgage borrowers and finding indirect support for the put option theory because "homeowners who have suffered a 20 percent or greater fall in house prices are about fourteen times more likely to default on a mortgage as compared to homeowners who have enjoyed a 20 percent increase"); Julapa Jagtiani \& William W. Lang, Strategic Default on First and Second Lien Mortgages During the Financial Crisis (Fed. Reserve Bank of Phila. Working Paper No. 11-3, 2010), http://ssrn.com/abstract=1724947 (finding empirical support for the put option theory but noting that many homeowners did not default on second liens, particularly home equity lines of credit); Thomas Schelkle, Mortgage Default During the U.S. Mortgage Crisis (Job Market Paper, Sept. 16, 2013) (concluding that the double-trigger model is better supported by empirical data), http://typo3-8442.rrz.uni-koeln.de/fileadmin/wiso_fak/cmr/pdf/Sche lkle_Publication_List/MD.pdf; see also Andra C. Ghent \& Marianna Kudlyak, Recourse and Residential Mortgage Default: Evidence from U.S. States, 24 REV. FIN. STUD. 3139 (2011) (finding that differences in state recourse laws have a significant effect on mortgage default among negative equity borrowers); Neil Bhutta et al., The Depth of Negative Equity and Mortgage Default Decisions (Fed. Reserve Bd. Working Paper No. 2010-35, 2010), http://ssrn.com/abstract=1895493. 
economic incentives. An individual borrower with a 3\% down payment is more likely to default than a borrower with a $20 \%$ down payment if home prices fall $15 \%$. Since foreclosure typically leads to a fire sale at a depressed price, one borrower's default and foreclosure can lead to a cascading cycle of falling prices and default by additional low-equity homeowners. The systemic implications of a high number of borrowers having low levels of home equity are simply not addressed by the ability-to-repay or qualified mortgage standards.

\section{B. Qualified Residential Mortgages and Minimum Down Payments}

The Dodd-Frank Act also established a second regulatory framework for mortgage lending, which contains an admirable-but somewhat misguidedattempt to address the danger posed by low-equity borrowing. Somewhat confusingly termed "qualified residential mortgages," this standard has only the slightest connection to the "qualified mortgage" framework discussed previously: the statute specifies that regulators' definition of "qualified residential mortgage" shall be "no broader" than the definition of "qualified mortgage." 42 Indeed, under rules proposed in April 2011 by six federal agencies, the definition of a "qualified residential mortgage" (QRM) is identical to that of a "qualified mortgage" (QM), but contains additional restrictions. ${ }^{43}$ But there are two fundamental differences between the two regimes that demonstrate the shortcomings of the current regulatory approach with respect to low-equity clustering.

The QRM definition arises in the very different context of credit risk retention by mortgage securitizers. The Dodd-Frank Act added section 15G to the Securities Exchange Act of 1934, which directs federal agencies to promulgate regulations requiring "any securitizer to retain an economic interest in a portion of the credit risk for any residential mortgage asset that the securitizer, through the issuance of an asset-backed security, transfers, sells, or conveys to a third party." S44 Specifically, the statute mandates that the regulations "require a securitizer to retain not less than 5 percent of the credit risk for any asset that is not a qualified residential mortgage that is transferred, sold, or conveyed through the issuance of an asset-backed security by the securitizer." the assets that collateralize the asset-backed security are not qualified residential mortgages," even if the remainder of the collateral consists of QRM loans. ${ }^{46}$

\footnotetext{
42. 15 U.S.C. $\$ 780-11(\mathrm{e})(4)(C)(2012)$.

43. For a comprehensive discussion, see infra Section III.C.

44. 15 U.S.C. $\$ 780-11(b)(2)(2012)$.

45. Id. $\$ 78 \mathrm{o}-11(\mathrm{c})(1)(\mathrm{B})(\mathrm{i})(\mathrm{I})$.

46. Id. $\S 78 \mathrm{o}-11(\mathrm{c})(1)(\mathrm{B})(\mathrm{i})(\mathrm{II})$.
} 
The consequences of originating a non-QRM loan thus differ from those of originating a non-QM loan. ${ }^{47}$ Under section $129 \mathrm{C}$ of the Truth-in-Lending Act, a lender may freely originate non-QM loans as long as the ability-to-repay requirement is met. ${ }^{48}$ This means that if a lender chooses to originate a non-QM loan, it need only be able to demonstrate that it considered the borrower's credit history, income, employment status, etc. ${ }^{49}$ and performed the requisite income verification. ${ }^{50}$ On the other hand, originating a non-QRM loan forces a securitizer to retain $5 \%$ of the credit risk of that loan. As the securitization market drives the demand for mortgage origination, this direct financial penalty will render non-QRM loans more expensive and less prevalent.

The stronger incentive provided by the QRM standard reinforces the importance of its primary substantive difference from the QM definition. Under the proposed rules, a QRM must have a minimum down payment of $20 \%$ and maximum loan-to-value ratio of $80 \% .{ }^{51}$ Giving lenders a financial incentive to offer $20 \%$ down payment loans would certainly reduce the prevalence of lowequity loans, as long as appraisals are not wildly inflated. But as we discuss below, ${ }^{52}$ a high minimum down payment would also impose a heavy burden on creditworthy borrowers who lack the financial resources to come up with such a large cash payment. More fundamentally, imposing a minimum down payment reflects an inadequate approach to addressing the systemic risk posed by low-equity clustering. The proportion of homeowners left with negative equity when home prices fall is not only a function of the average down payment size, which is what the QRM proposal affects. As we explain in the next Part, the distribution of private contracting terms likely to induce low levels of equity is equally important.

QRM's strong incentive for lenders not to offer mortgages with less than a $20 \%$ down payment reflects a detrimentally narrow focus on reducing risky contracting. There is always a risk-reward tradeoff: greater risk often implies greater reward, and the QRM proposal makes no mention of the beneficial effects of limited amounts of speculation in the housing market. When the

47. But see discussion of new QRM proposed rule infra note 150.

48. 15 U.S.C. $\$ 1639 \mathrm{c}(\mathrm{b})(1)$ (2012) ("Any creditor with respect to any residential mortgage loan, and any assignee of such loan subject to liability under this subchapter, may presume that the loan has met the requirements of subsection (a), if the loan is a qualified mortgage." (emphasis added)). This indicates that the qualified mortgage standard is merely a presumption of compliance with the ability-to-repay standard.

49. Id. $\S 1639 \mathrm{c}(\mathrm{a})(3)$.

50. Id. $\S 1639 \mathrm{c}(\mathrm{a})(4)$. However, some lenders have pointed out that QM may end up defining the contours of most mortgage products offered because lenders will wish to avoid any potential legal liability. See CFPB Considers Protecting Lenders Under Qualified Mortgage Rule, HOUSINGWIRE (Oct. 16, 2012), http://www.housingwire.com/articles.cfpb-considers-protecting-lenders -under-qualified-mortgage-rule (citing a Compass Point research note concluding that "the QM rulemaking will largely define the contours of mortgage lending").

51. Credit Risk Retention Proposed Rule, 76 Fed. Reg. 24,090, 24,124 (Apr. 29, 2011). For a detailed discussion of the $20 \%$ down payment requirement, see infra Section III.C.

52. See discussion infra Section III.C. 
economy is mired in a recession or even a temporary slowdown, erecting artificial barriers to credit-such as a $20 \%$ minimum down payment requirement-can needlessly reduce liquidity and cripple demand. The overbroad down payment requirement in the proposed QRM standard is simply not narrowly tailored to the goal of reducing systemic risk.

Indeed, a regulatory paradigm that focuses on the distribution of privately contracted terms permits calibrating the precise level of risky terms that would be socially optimal. ${ }^{53}$ For example, through a system such as the leverage licensing regime we propose below, ${ }^{54}$ regulators could permit $2 \%$ of new mortgages to have a very low down payment, which would bring society the benefits of a low quantity of risky contracting without the costs of too much. And of course, regulating the distribution of contract terms permits raising the mean (or median) level of equity as well. Regulators could simply license $51 \%$ of new mortgages at a $20 \%$ down payment level and thereby ensure that on average new mortgages would remain low-risk from an initial equity standpoint.

In short, QM and QRM both reflect an overly narrow regulatory paradigm of prohibiting risky contract terms rather than considering the distribution of those terms in the borrower population. In particular, the regulatory response to the crisis has not adequately considered the aggregate effect of low-equity clustering among the borrower population when home prices drop and liquidity dries up. The next Part will show that the housing crisis beginning in 2007 was preceded by a high concentration of low levels of equity, which amplified the harm caused by falling home prices by pushing a larger cohort of borrowers underwater. As this leads to higher levels of default and foreclosures, reducing home prices even further, low-equity clustering contributes directly to systemic risk in the housing market.

\section{The Economic Effect of Low-Equity Clustering}

One factor affecting the overall stability of the housing market is the system-wide distribution of home equity. Average equity levels are undoubtedly important: a population with greater home equity on average would have fewer homeowners below the zero-percent level when housing prices fall. Yet the distribution of equity levels is also crucial: if more homeowners are tightly clustered together at a low level of equity, a drop in housing prices beyond this level pushes proportionately more homeowners into negative equity than if borrowers are spread evenly across the equity spectrum. As increased default can lead to a cycle of falling housing prices through

53. Put differently, where the marginal benefit of a certain quantity of risky terms is

54. See discussion infra Section IV.A. 
foreclosures and short sales, low-equity clustering represents a form of systemic risk to the housing market. ${ }^{55}$

Mechanisms that prevent low-equity clustering can be likened to flood levies that provide multiple layers of protection in the event of a disaster. Each additional level of home equity provides an additional safeguard. For example, if all of the homeowners in a given population are clustered around the $5 \%$ equity level, a drop in home values of $10 \%$ pushes every homeowner in the population into negative equity. However, if half of the population held $15 \%$ equity loans (and the remainder held 5\% equity), that half would remain in positive equity even if home values dropped by $10 \%$. Similarly, if $1 / 3$ of the population were at the $5 \%$ equity level, $1 / 3$ at the $12 \%$ level, and $1 / 3$ at the $15 \%$ level, even fewer homeowners would be facing negative equity in the scenario where home prices dropped by $10 \%$. This simple example illustrates that increased distribution of home equity reduces the danger from low-equity clustering. Indeed, since the exact drop in home prices is unknown in advance, it might seem prudent to encourage an even and smooth distribution of equity so as to minimize the number of homeowners who would be pushed into negative equity with any decrease in home prices. In terms of flood levies, one might argue that more levies are better because they provide redundant protection.

However, such an approach carries its own risks. In particular, equity that is spaced too smoothly can lead to a "domino effect" in which one small drop in prices triggers a cascading cycle of default and decreasing prices. For example, a drop in prices of $2 \%$ would push homeowners at the $1 \%$ equity level into negative equity and subsequent default. Even if the resulting foreclosure or distressed sale only further depressed prices by $1 \%$, that would push homeowners at the $2 \%$ equity level into negative equity and subsequent default. This cascading cycle of dropping prices and default would expose the housing market to a much higher level of systemic risk than the scenario in which homeowners were clustered at the $10 \%$ level. Indeed, in this example, no homeowner would be pushed into negative equity in the clustering scenario, whereas a smooth distribution of equity could expose every homeowner located along the cascading chain of falling prices to negative equity and subsequent default.

Admittedly, this scenario of cascading default might seem unrealistic in light of the economic research that shows that homeowners do not necessarily default in response to very small levels of negative equity. Moreover, the requisite liquidity shocks might not be present in cases where exogenous

55. Reducing low-equity clustering also has informational benefits in addition to reducing systemic risk. Greater diversity in the distribution of equity provides a "miner's canary," an early warning system that something is wrong without triggering the cascading effect of foreclosures leading to prices falling further. We discuss these informational benefits in detail in Ian Ayres \& Joshua Mitts, Anti-Herding Regulation (2013) (unpublished manuscript) (on file with authors). 
factors lead to only a minor drop in home prices. As substantial decreases in home values often result from asset bubbles whose popping leads to increased credit constraints, the more typical scenario would see drops in home values on the order of $10-15 \%$ rather than $1 \%$. Nonetheless, the concern of a domino effect is present even at higher levels of home equity: a drop in prices by $10 \%$ might trigger a cascading cycle of falling prices at the $9 \%$ equity level, followed by $10 \%, 11 \%$, etc. Thus, when considering mechanisms to reduce low-equity clustering, it might be beneficial to consider "circuit breakers"empty ranges of equity levels that could absorb small decreases in prices by keeping homeowners above the range in positive equity. For example, in the case where home prices fall by $10 \%$, a gap in equity between $10-12 \%$ would ensure that any subsequent drops in home values from $10 \%$ to $11 \%$ would not lead to a further drop from $11 \%$ to $12 \%$. Indeed, the regulatory regime proposed in this Article includes a monitoring component that enables maintaining these "circuit breakers" alongside a non-clustered distribution of mortgage leverage. 56

This discussion is not merely hypothetical, for the effect of low-equity clustering is ultimately an empirical question. In Section II.A, we summarize existing empirical research that suggests that certain mortgage terms and equity extractions preceded the housing crisis. In Section II.B, we present the results of an original empirical study we conducted, which are consistent with the hypothesis that more concentrated levels of equity led to greater declines in home prices and higher levels of mortgage default during the crisis period.

\section{A. Existing Research on Low-Equity Clustering}

To demonstrate the importance of regulating the distribution of home equity, this Section presents empirical studies of the impact of low-equity clustering on home prices and default over the past decade. ${ }^{57}$ One recent study by Bostic et al. shows that the prevalence of risky mortgage terms rose dramatically during the housing bubble, as indicated in the table below, which contains a breakdown of home mortgages in 1999, 2003, and $2006^{58}$ :

56. See discussion infra Subsection IV.A.3.

57. We define equity as the difference between the purchase price of the home and the mortgage principal balance, which typically includes closing costs as well.

58. Raphael W. Bostic et al., Mortgage Product Substitution and State Anti-Predatory Lending Laws: Better Loans and Better Borrowers? (U. Penn Inst. Law \& Econ. Research Paper No. 0927,2012 ), http://ssm.com/abstracy=1460871. The following tables, maps, and headings are directly excerpted from this research paper. 
Table 1: Selected Sample Statistics, 1999, 2003, and 2006 (All Loans) ${ }^{59}$

\begin{tabular}{lrrr}
\hline & $\mathbf{1 9 9 9}$ & $\mathbf{2 0 0 3}$ & $\mathbf{2 0 0 6}$ \\
\hline Number of Loans (A11 Loans) & 596,710 & $1,840,040$ & $3,251,355$ \\
Interest-Only Loans & $\mathbf{0 . 2 0 \%}$ & $5.21 \%$ & $22.31 \%$ \\
Balloon Loans & $11.56 \%$ & $5.07 \%$ & $25.01 \%$ \\
Balloon ARM Loans & $0.20 \%$ & $0.00 \%$ & $11.41 \%$ \\
ARM Teaser Loans & $28.92 \%$ & $19.66 \%$ & $50.43 \%$ \\
Average Loan Amount & $\$ 96,092$ & $\$ 165,755$ & $\$ 200,990$ \\
Loans With Prepayment Penalty & $51.47 \%$ & $58.43 \%$ & $54.26 \%$ \\
\hline
\end{tabular}

The dramatic rise in interest-only loans, balloon loans, and ARM teaser loans directly contributed to low-equity clustering. This may be seen in the following maps excerpted from the Bostic et al. study:

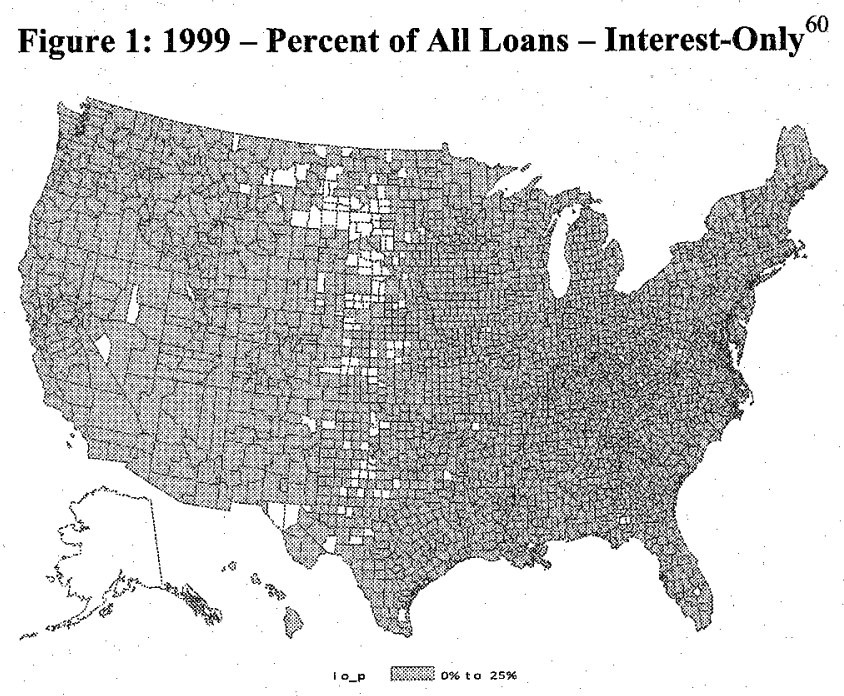

59. Id. at 29. The loan quantities have been transformed into percentages.

60. Id. at 40 . 
Figure 2: 2006 - Percent of All Loans - Interest-Only ${ }^{61}$

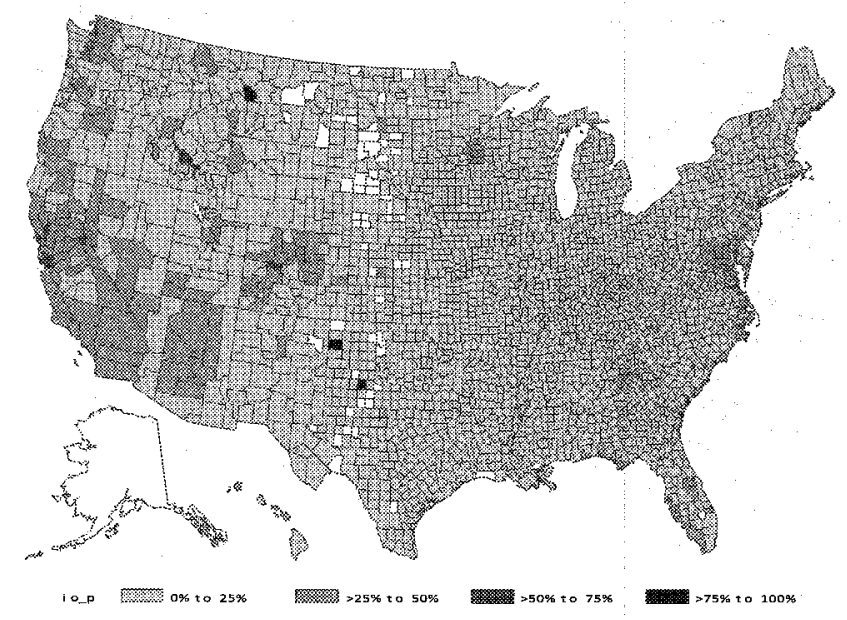

In these maps showing the proportion of interest-only loan originations in 1999 and 2006, one can quickly see these terms were concentrated in California and a few select non-California counties where more than $25 \%$ of originations - and at times more than $50 \%$ of originations - were made on an interest-only basis.

Figure 3: 1999 - Percent of All Loans - Balloon ${ }^{62}$

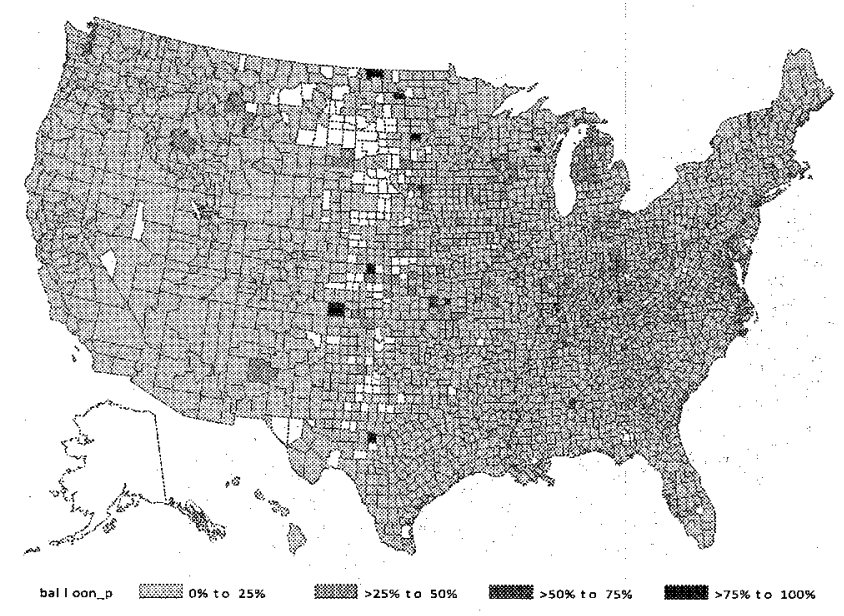

61. Id.

62. Id. at 41 . 
Figure 4: 2006 - Percent of All Loans - Balloon ${ }^{63}$

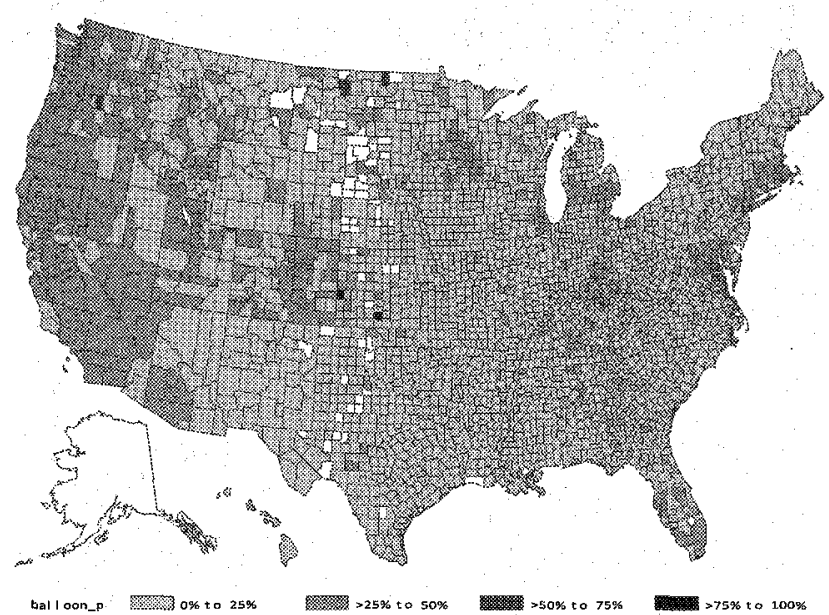

An analogous pattern can be seen in this pair of maps showing the increased prevalence and concentration of mortgage originations with balloon payment conditions.

Finally, the following figure taken from the study shows the nearly universal dominance of teaser rates in the 2006 market, as more than $75 \%$ of the originations in virtually all counties were teaser ARM loans:

Figure 5: 2006 - Percent of Adjustable Rate Loans with a Teaser ${ }^{64}$

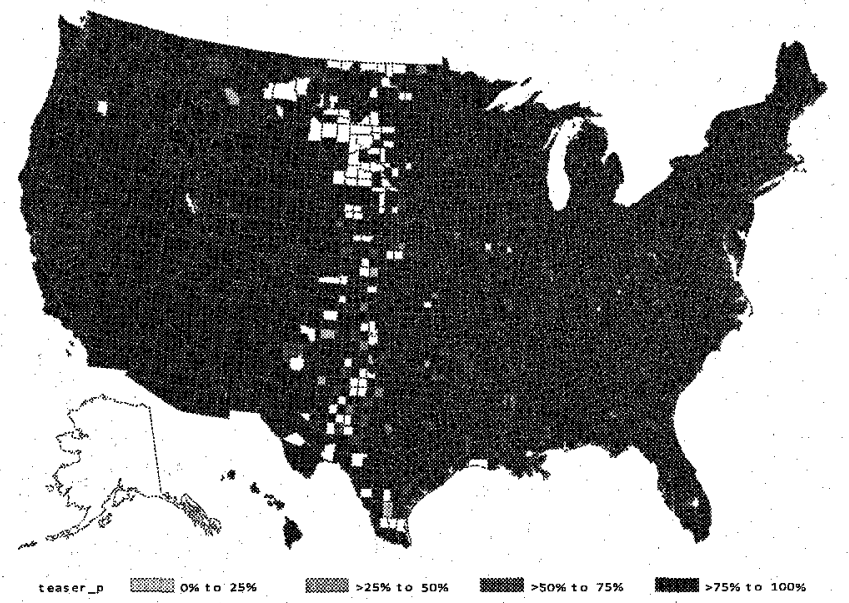

63. Id.

64. Id. at 42 . 
Other studies have directly examined the role of equity stripping in the housing bubble of the mid-2000s. The following estimates by former Federal Reserve Chairman Alan Greenspan and James Kennedy demonstrate the dramatic rise of equity extraction:

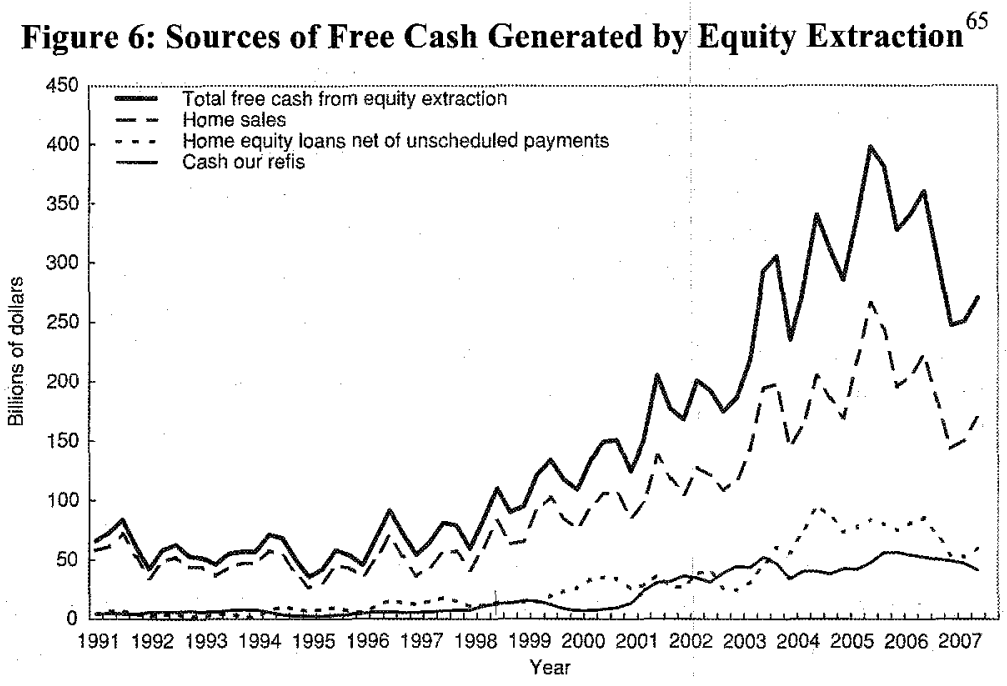

Figure 6 shows that equity extractions rose dramatically over the prior decade, rarely topping $\$ 100$ billion in the years 1991-2000 yet skyrocketing to approximately $\$ 400$ billion in $2005 . .^{66}$ Surveys of cashout refinance borrowers suggest that a substantial proportion of funds converted to cash were used for personal consumption expenditures (including vacations) ${ }^{67}$ These findings are consistent with evidence that homeowners utilized home equity loans to finance discretionary spending. ${ }^{6}$

In a study that strongly supports this paper's thesis, Amir E. Khandani, Andrew W. Lo, and Robert C. Merton estimated the extent to which "equity extractions" in the years leading up to the housing crisis led to an "unintentional synchronization of leverage" that increased the correlation of

65. This figure and the following graph and heading are excerpted from Alan Greenspan \& James Kennedy, Sources and Uses of Equity Extracted from Homes, 24 OXFORD REV. ECON. POL'Y 120, 125 (2008).

66. Id.

67. Id. at 126. For an example found in a news story at the height of the bubble, see Michael Rubinkam, Home Equity Used to Finance Super Bowl Trips, Hous. CHRON., Feb. 2, 2005, http://www.chron.com/business/article/Home-equity-used-to-finance-Super-Bowl-trips-1660034.php.

68. E.g., Atif Mian \& Amir Suf,, House Prices, Home Equity-Based Borrowing, and the U.S. Household Leverage Crisis, 101 AM. ECON. REV. 2132, 2152 (2011) (finding that "a large fraction of home equity-based borrowing is used for consumption or home improvement"). 
mortgage default among homeowners. ${ }^{69}$ An equity extraction occurs when a homeowner obtains a "cash-out" refinancing loan or home equity loan, or sells his or her home and obtains a new mortgage with a higher loan-to-value ratio, retaining the proceeds from the sale as cash. ${ }^{70}$ Khandani et al. explain the "selfsynchronizing ratchet effect," which renders low-equity clustering such a potent source of systemic risk:

$[R]$ efinancing-related increases in leverage cannot be symmetrically reduced when property values decline because homes are indivisible .... Once property values decline, a wave of defaults becomes unavoidable because mortgage lenders have no mechanism such as a margin call to compel homeowners to add more equity to maintain their leverage ratio, nor can homeowners reduce their leverage in incremental steps by selling a portion of their homes and using the proceeds to reduce their debt. This self-synchronizing "ratchet effect" of the refinancing market can create significant systemic risk in an otherwise geographically and temporally diverse pool of mortgages, steadily increasing the aggregate leverage of the housing market until it reaches a systemically critical threshold. $^{71}$

Indeed, this is what fundamentally distinguishes mortgage leverage synchronization from similar synchronization in liquid securities: unlike with stocks or bonds in an investment portfolio, a homeowner cannot sell a portion of his or her physical home to reduce leverage. ${ }^{72}$ Greater leverage synchronization thus increases systemic risk because a drop in home prices leads to highly correlated set of defaults among homeowners clustered at low levels of equity. ${ }^{73}$

Khandani et al. provide empirical support for the ratchet effect by using data regarding accumulated equity in mid-2006, once housing prices began to fall, to simulate the expected level of negative equity at the end of $2008 .^{74}$ In their simulation, "approximately $18 \%$ of all mortgage loans exhibit negative equity as of December 2008, which is nearly identical to the actual figure reported by industry sources." that period without equity extractions is $3 \%$, meaning that the refinancing ratchet effect caused $15 \%$ of mortgages to have negative equity in the

69. Amir E. Khandani et al., Systemic Risk and the Refinancing Ratchet Effect 3 (Nat'l Bureau of Econ. Research Working Paper No. 15362, 2009); see also Greenspan \& Kennedy, supra note 65 (estimating equity extractions from 1991-2006).

70. See Greenspan \& Kennedy, supra note 65, at 122; Alan Greenspan \& James Kennedy, Estimates of Home Mortgage Originations, Repayments, and Debt on One-to-Four-Family Residences 5-6 (Fed. Reserve Bd. Fin. \& Econ. Discussion Series No. 2005-41, 2005).

71. Khandani et al., supra note 69, at 2.

72. See id. at 2 .

73. Cf. id. at 3.

74. See id. at 4.

75. Id. 
simulation. ${ }^{76}$ Accordingly, low-equity clustering through cash-out refinancing made a substantial contribution to systemic risk in the housing market by placing more owners at risk of falling into negative equity.

\section{B. An Original Empirical Study on Low-Equity Clustering}

As an additional demonstration of the contribution of low-equity clustering, we conducted an empirical study that examined home equity levels of over 20,000 homeowners across eleven states from 1999 to 2011 . Our results found that higher levels of low-equity clustering correlate with increased mortgage delinquency even after controlling for macroeconomic shocks. While imperfections in the data preclude establishing strong causal explanations, the results nonetheless serve as heuristic evidence of the need to attend to the problem of low-equity clustering.

\section{Research Design}

When conducting this study, we set out to examine the impact of lowequity clustering on home prices and mortgage default. As falling home prices and increased default feed each other in a cascading cycle, we measure the effect of low-equity clustering on each independently. We examine these two variables on a quarterly basis from the first quarter of 1999 to the first quarter of 2011 across eleven highly populated states: Arizona, California, Florida, Illinois, Michigan, Nevada, New Jersey, New York, Ohio, Pennsylvania, and Texas. ${ }^{77}$ State-level quarterly home price data were obtained from the Federal Housing Finance Agency (FHFA). ${ }^{78}$ State-level quarterly mortgage delinquency rates were obtained from the Federal Reserve Bank of New York. ${ }^{79}$

Data on home equity levels were derived from the U.S. Department of Labor Bureau of Labor Statistics Consumer Expenditure Survey, a quarterly survey of consumers on household income and expenditures. ${ }^{80}$ The survey asks

76. $I d$.

77. These states and years were selected because data on mortgage default were freely available from the Federal Reserve Bank of New York for these states and years alone. See Quarterly Report on Household Debt and Credit, FED. RESERVE BANK OF N.Y. 22 (2011), http://www.newyorkfed.org/research/national_economy/householdcredit/DistrictReport_Q32011.xlsx.

78. These data may be found at Downloadable HPI Data, FED. HousING FIN. AGENCY, http://www.fhfa.gov/Default.aspx?Page=87 (last visited Feb. 14, 2014). The study utilized the data through 2011Q3 from the dataset entitled "States through 2013Q4 (Not Seasonally Adjusted)" under "All-Transactions Indexes (Estimated using Sales Prices and Appraisal Data)."

79. See FED. RESERVE BANK OF N.Y., supra note 77, at 22 (showing the state-level data as "Percent of Mortgage Debt 90+ Days Late by State").

80. Consumer Expenditure Survey, U.S. DEP'T OF LABOR BUREAU OF LABOR STATISTICS, http://www.bls.gov/cex (last visited Feb. 14, 2014). For a detailed description of how the survey is conducted, see Consumer Expenditures and Income, in BLS HANDBOOK OF METHODS (2013), http://www.bls.gov/opub/hom/pdf/homchl6.pdf. 
homeowners to state their outstanding mortgage principal balance for each month as well as the estimated current value of their home. We divided the monthly principal balances by the estimated home value to produce a monthly equity level, which we averaged to produce a quarterly equity level for each homeowner. ${ }^{81}$ While homeowners' estimates of the value of their own homes may be imprecise and may even systematically understate or overstate house values, these estimates will be sufficient for our purposes so long as they are correlated with homes' true values and any bias is orthogonal to the degree of leverage (and other potential influences on market behavior).

We estimate the prevalence of low-equity clustering in several ways. First, we compute the standard deviation of home equity levels in each state-quarter. The standard deviation can serve as a useful measure of the dispersion of the data in general: the lower the standard deviation, the more the data are clustered around their mean. Of course, for the standard deviation to be useful for measuring low-equity clustering, it is essential to measure the mean as well. The study thus computed the mean of home equity levels in each state-quarter. When taken together, the mean and standard deviation of equity levels provide a useful picture of the degree of low-equity clustering. In addition, as an alternative measure of low-equity clustering, the proportion of homeowners with less than $20 \%$ equity was computed by dividing the number of homeowners with less than $20 \%$ equity by the number of homeowners with mortgages in each state-quarter.

Finally, we obtained the state-level seasonally adjusted unemployment rates from the U.S. Department of Labor Bureau of Labor Statistics. ${ }^{82}$ The unemployment rate reflects crisis conditions at the macroeconomic level and

81. At a technical level, this computation was conducted as follows. First, the microdata for each year in the Consumer Expenditure Survey dataset were downloaded. (The following column/table names refer to the CES microdata.) Next, the monthly mortgage principal balances were extracted from the "QBLNCM1," "QBLNCM2," and QBLNCM3" columns in the "MOR" table. Property values were obtained from the "PROPVALX" column in the "OPI" table by matching the "NEWID" and "PROP_NO" columns from the "MOR" table with the same columns in the "OPI" table. Finally, the geographic state of the consumer was obtained by matching the "NEWID" column in the "MOR" table with the "NEWID" column in the "FML" quarterly tables, which contain biographical information on the consumer unit. An objection might be raised that it is inaccurate to compute average quarterly equity based on the estimated property value at the time the survey is completed because that estimate occurs at the end of the quarter when the survey is taken. Admittedly, this estimation lacks sufficient specificity to capture precise intra-quarter equity levels, e.g., on a month-by-month basis. However, it seems to be the best available alternative. Using solely the third-month principal balance in the equity computer would arguably lead to a greater distortion because it would omit any intra-quarter change in principal, which might be much more substantial. For example, a homeowner might refinance into a lower-equity loan in the second month, leading to a higher principal balance in the third month. In such a scenario, it would be inaccurate to utilize an equity level reflecting the third month alone because the prior two months of the quarter had a lower principal level. This increased leverage should be weighted appropriately as one third of the quarter, not $100 \%$.

82. Local Area Unemployment Statistics, U.S. DEP'T OF LABOR BUREAU OF LABOR STATISTICS, http://www.bls.gov/lau (last visited Feb. 14, 2014). 
can thus function as a general proxy for income and liquidity shocks. ${ }^{83}$ of course, this proxy is imperfect. In light of the depth and breadth of the financial crisis of 2008 , conditions were likely so vastly different during this period that it is necessary to consider those quarters separately. Accordingly, a crisisperiod dummy variable was set as 1 beginning in the third quarter of 2007 , which is when the uptick in unemployment begins, coinciding with tightening credit conditions as a result of the subprime mortgage and ensuing financial crisis.

\section{Econometric Model and Regression Results}

Our core interest is to test whether states with greater low-equity clustering experienced greater declines in housing prices and greater defaults. The regressions utilized in the study employ the following econometric model for panel data with a one-way error component and state fixed effects ${ }^{84}$ :

$$
y_{i t}=\alpha+X^{\prime}{ }_{i t} \beta+\mu_{i}+v_{i t} i=1, \ldots, N ; t=1, \ldots, \mathrm{T}
$$

with:

$$
\begin{aligned}
& i=\text { states } \\
& t=\text { quarters } \\
& X_{i t}^{\prime}=i t \text { th observation on } K \text { explanatory variables } \\
& \beta=K \times 1 \text { (coefficient matrix) } \\
& \mu_{i}=\text { fixed parameters for each state (dummies) } \\
& v_{i t}=\text { i.i.d. stochastic remainder disturbances. }
\end{aligned}
$$

We begin by looking at the impact of pre-crisis low-equity clustering on post-crisis price falls and default rates. Controlling for other factors, including mean pre-crisis equity, we want to test whether states with lower standard deviations in equity experienced larger price drops and higher default rates. The regression uses the FHFA Drop in Home Prices and FHFA Rise in Home Prices variables defined in the statistical appendix, examining the effect of precrisis low-equity clustering on home prices throughout the crisis period. This regression uses exclusively fixed group-level independent variables. In addition to the FHFA Rise in Home Prices, three state-level variables are defined: the standard deviation of equity in the third quarter of 2006 , the mean equity in the

83. Admittedly, the unemployment rate cannot serve as a proxy for income or liquidity shocks caused by individual, idiosyncratic circumstances such as divorce or illness. Nonetheless, these years experienced substantial liquidity shocks from rapidly increasing unemployment resulting from decreased demand and credit constraints. See generally FIN. CRISIS INQUIRY COMM'N, supra note 11, at 389-401.

84. Details of our modeling are included in a statistical appendix. This model is based on the standard panel data model with a one-way error component and fixed effects found in BADI $H$. BALTAGI, ECONOMETRIC ANALYSIS OF PANEL DATA 12 (2d ed. 2002). 
third quarter of 2006 , and the proportion of homeowners with less than $20 \%$ equity in the third quarter of $2006 .^{85}$

The following regressions examine the effect of these variables on falling home prices during the crisis period. As these contain exclusively fixed terms on the right-hand side, ordinary least squares regression is employed. ${ }^{86}$

\section{Table 2: FHFA Drop in Home Prices \& Mean/Standard Deviation of Equity}

\begin{tabular}{lrc}
\hline & \multicolumn{2}{c}{ FHFA Drop in Home Prices } \\
\cline { 2 - 3 } & Mean $(\boldsymbol{\mu})$ & Standard Deviation $(\boldsymbol{\sigma})$ \\
\hline Standard Deviation of Equity (2006q3) & -0.964 & $(0.175)^{* *}$ \\
Mean Equity (2006q3) & -0.654 & $(0.197)^{* *}$ \\
FHFA Rise in Home Prices & 0.613 & $(0.085)^{* *}$ \\
Constant Term & 0.437 & $(0.101)^{* *}$ \\
\hline$R^{2}$ & 0.33 \\
$N$ & 165 \\
\hline \multicolumn{3}{|}{} \\
\end{tabular}

Table 3: FHFA Drop in Home Prices \& Proportion of Homeowners Less Than $20 \%$ Equity

\begin{tabular}{|c|c|c|}
\hline & \multicolumn{2}{|c|}{ FHFA Drop in Home Prices } \\
\hline & $\mu$ & $\boldsymbol{\sigma}$ \\
\hline Proportion of Homeowners <20\% Equity (2006q3) & 0.381 & $(0.180)^{*}$ \\
\hline FHFA Rise in Home Prices & 0.493 & $(0.082)^{* *}$ \\
\hline Constant Term & -0.194 & $(0.072)^{* *}$ \\
\hline$R^{2}$ & 0.22 & \\
\hline$N$ & 165 & \\
\hline
\end{tabular}

As expected, a lower pre-crisis mean and standard deviation of equity lead to a greater drop in home prices. Similarly, a greater proportion of homeowners with less than $20 \%$ equity correlated with a greater drop in home prices. These findings support the conclusion that low-equity clustering increases systemic risk by leading to falling home prices, which push more homeowners into negative equity and subsequent default.

85. The third quarter of 2006 was chosen because it is the period immediately preceding the peak of the home prices from which the drop in home prices was calculated. It is thus arguably representative of the bubble before shifting market conditions started changing the distribution of equity.

86. There is no need to control for heteroskedasticity, serial correlation, or crosssectional dependence because there is no right-hand side variation. Essentially, these regressions compare the varying state-specific levels of mean, standard deviation, and proportion of homeowners under $20 \%$ equity for the movement in each state-quarter's default rate independently, which works fine with constant terms on the right-hand side. 
Using the default rate as our dependent variable produces similar results. In light of the constant nature of the independent variables, it is necessary to control for the state-level variation in the size of the housing bubble (rise in prices), as this would affect the severity of the increase in the default rate in each state. Below are the results of these ordinary least square regressions, which examine the effect of the mean, standard deviation, and proportion of homeowners with less than $20 \%$ equity on the default rate during the crisis period:

Table 4: Default Rate \& Mean/Standard Deviation of Equity

\begin{tabular}{|c|c|c|}
\hline & \multicolumn{2}{|c|}{ Default Rate } \\
\hline & $\mu$ & $\sigma$ \\
\hline Standard Deviation of Equity (2006q3) & -0.144 & $(0.066)^{*}$ \\
\hline Mean Equity (2006q3) & -0.195 & $(0.074)^{* *}$ \\
\hline FHFA Rise in Home Prices & 0.176 & $(0.032)^{* *}$ \\
\hline Constant Term & 0.121 & $(0.038)^{* *}$ \\
\hline$R^{2}$ & 0.19 & \\
\hline$N$ & 165 & \\
\hline
\end{tabular}

Table 5: Default Rate \& Proportion of Homeowners Less Than 20\% Equity

\begin{tabular}{lrc}
\hline & \multicolumn{2}{c}{ Default Rate } \\
\cline { 2 - 3 } & \multicolumn{1}{c}{$\boldsymbol{\mu}$} & \multicolumn{1}{c}{$\boldsymbol{\sigma}$} \\
\hline Proportion of Homeowners Under 20\% Equity (2006q3) & 0.248 & $(0.062)^{* *}$ \\
FHFA Rise in Home Prices & 0.189 & $(0.028)^{* *}$ \\
Constant Term & -0.071 & $(0.025)^{* *}$ \\
\hline$R^{2}$ & 0.22 & \\
$N$ & 165 & \\
\hline & &
\end{tabular}

As expected, a lower mean and standard deviation of equity leads to a higher default rate. Similarly, a greater proportion of homeowners with less than $20 \%$ equity correlates with a higher default rate. Along with the previous regression results, these data support the conclusion that low-equity clustering increases systemic risk by leading to higher levels of mortgage default.

\section{Home Price Regressions}

To further strengthen the argument that low-equity clustering increases the likelihood of default, it is helpful to consider its effect on home prices. As described above, falling home prices are an essential link in the chain of events leading to increased default: as home prices fall, low-equity clustering leads to more homeowners being pushed into negative equity and subsequent default upon experiencing a liquidity shock. Accordingly, establishing a link between 
low-equity clustering and falling home prices would provide additional support for the argument that low-equity clustering increases systemic risk.

The following two regressions employ the same independent variables as above, but define a different dependent variable and a new independent variable ${ }^{87}$ The rationale behind these two variables is that in order to capture the effect of low-equity clustering on falling home prices, it is necessary to measure the drop in home prices from their pre-crisis peak to each quarter employed in the time-series regression. Accordingly, the fhfadrop variable was defined as the difference between each state's home price index in the fourth quarter of 2006 and in the current quarter. ${ }^{88}$ As different states might have had larger "bubbles" in home values than others, the fhfarise variable was defined as the difference between this pre-crisis peak and the initial home price index in the first quarter of 1991. By controlling for the rise in home values, a regression examining the drop in home prices can focus exclusively on the variables responsible for relatively greater decreases across states.

Of course, as the aforementioned definitions imply, in order to compare larger home price bubbles across states, it is necessary to remove the fixed effects constraint. These regressions thus examine not only whether variables such as the standard deviation of equity, mean equity, and the proportion of homeowners with less than $20 \%$ equity explain the variation of home prices within a state, but also whether they explain differences in decreasing home prices across states in light of different state-specific increases in prices. ${ }^{89}$

Below are the results of the two regressions, one utilizing the standard deviation of equity and mean equity, and the other utilizing the proportion of homeowners with less than $20 \%$ equity. ${ }^{90}$ Each examines the effect of these

87. The two variables are defined as follows, where fhfaindex is the FHFA Home Price Index for the state-quarter:

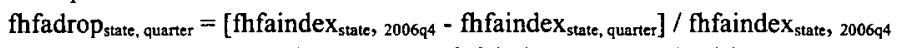

fhfarise $_{\text {state, quarter }}=\left[\right.$ fhfaindex $_{\text {state, } 2006 \mathrm{q} 4}-$ fhfaindex $\left._{\text {state, }}, 1999 \mathrm{q} 1\right] /$ fhfaindex $_{\text {state, }}, 1999 \mathrm{q} 1$.

88. The fourth quarter of 2006 was the quarter containing the highest aggregate FHFA home price index (sum total of FHFA index for each state) in the dataset. This was utilized to ensure an appropriate comparison across states, even if their state-specific highest home price index value might have been in one of the surrounding quarters.

89. While there is no theoretical explanation for why factors affecting the default rate should vary across states, there is a strong reason why the extent of the decrease in home prices would indeed vary across states. The decrease in home prices depends on their rise up to that point, which plainly varies across states. On the other hand, changes in the default rate within a given state should depend on the distribution of equity within that state, and there is no theory for why these variables (standard deviation, mean, and proportion of homeowners under $20 \%$ equity) would necessarily vary across states. Put differently, a variable measuring the drop in home prices necessarily implies a random effects model, whereas a variable measuring simply the rate of default in a given region can be examined under a fixed-effects framework in the absence of a theoretical justification for between-group variation. For a further discussion of the difference between fixed and random effects, see BALTAGI, supra note 84 , at $12-20$.

90. As with the first two regressions, these utilize panel-corrected standard errors to control for heteroskedasticity, serial correlation, and cross-sectional dependence. Just as with the default rate, these phenomena would be present when examining the effect of low-equity clustering on home 
variables on the drop in home prices, controlling for their rise, during the crisis period. There is no lag employed, because unlike the default rate, which measures the incidence of loans with 90-plus days of nonpayment, the effect of low-equity clustering on falling home prices does not have any inherent delay.

Table 6: FHFA Drop in Home Prices \& Mean/Standard Deviation of Equity, Time-Series

\begin{tabular}{lcc}
\hline & \multicolumn{2}{c}{ FHFA Drop in Home Prices } \\
\cline { 2 - 3 } & $\boldsymbol{\mu}$ & $\boldsymbol{\sigma}$ \\
\hline Standard Deviationof Equity & -0.249 & $(0.077)^{* *}$ \\
Mean Equity & -0.695 & $(0.099)^{* *}$ \\
Unemployment Rate & 1.368 & $(0.429)^{* *}$ \\
FHFA Rise in Home Prices & 0.595 & $(0.054)^{* *}$ \\
Constant Term & 0.115 & $(0.058)^{*}$ \\
\hline$R^{2}$ & 0.810 & \\
$N$ & 165 & \\
\hline
\end{tabular}

${ }^{*} p<0.05 ;{ }^{* *} p<0.01$

Table 7: FHFA Drop in Home Prices \& Proportion of Homeowners Less Than 20\% Equity, Time-Series

\begin{tabular}{lrc}
\hline & \multicolumn{3}{c}{ FHFA Drop in Home Prices } \\
\cline { 2 - 3 } & \multicolumn{1}{c}{$\boldsymbol{\mu}$} & \multicolumn{1}{c}{$\boldsymbol{\alpha}$} \\
\hline Proportion of Homeowners Under 20\% Equity & 0.474 & $(0.086)^{* *}$ \\
Unemployment Rate & 1.193 & $(0.393)^{* *}$ \\
FHFA Rise in Home Prices & 0.480 & $(0.063)^{* *}$ \\
Constant Term & -0.339 & $(0.042)^{* *}$ \\
\hline$R^{2}$ & 0.59 & \\
$N$ & 165 & \\
\hline
\end{tabular}

${ }^{*} p<0.05 ;{ }^{* *} p<0.01$

prices as well. Moreover, tests in Stata confirm that each is present. Below is the test for heteroskedasticity (xttest 3 ):

H0: $\operatorname{sigma}(i)^{\wedge} 2=\operatorname{sigma}^{\wedge} 2$ for all $\mathrm{i}$

chi2 $(11)=319.38$

Prob $>$ chi2 $=0.0000$

Serial correlation (xtserial):

Wooldridge test for autocorrelation in panel data:

H0: no first-order autocorrelation

$F(1,10)=242.638$

Prob $>\mathrm{F}=0.0000$

Cross-sectional dependence ( $x$ ttest 2 ) (correlation matrix omitted) . . .

Breusch-Pagan LM test of independence:

chi2(55) $=202.262, \operatorname{Pr}=0.0000$

Based on 15 complete observations over panel units. 
As expected, lower standard deviation of equity and mean equity have a statistically significant, positive effect on the drop in home prices. Greater lowequity clustering leads to a greater decrease in home prices, which in turn leads to higher levels of mortgage default as shown in the prior regressions. Similarly, as an alternative measurement of low-equity clustering, a higher proportion of homeowners under $20 \%$ equity leads to a higher drop in home prices. The relevance of low-equity clustering is thus supported by home price data as well.

\section{Default Rate Regressions}

This regression examines the effect of low-equity clustering on the default rate by measuring the extent to which variation in the standard deviation and mean levels of equity explain variation in the mortgage default rate during the crisis period alone (third quarter of 2007 to the first quarter of 2011). As the default rate reflects the proportion of homeowners who are ninety-plus days delinquent in their mortgage payments, the study employs a two-quarter lag for the standard deviation and mean levels of equity. The decision to default would have occurred at least two quarters prior to the time at which such a decision would be reflected in the default rate. However, the regression employs only a one period lag for the unemployment rate, because the liquidity shock that would lead a homeowner to default would require approximately one quarter before being reflected in the unemployment rate proxy. ${ }^{91}$

The results of the regression are as follows ${ }^{92}$ :

91. This follows from the definition of unemployment as actively looking for work within the last four weeks, utilized by the Bureau of Labor Statistics. How the Government Measures Unemployment, BUREAU OF LABOR STATISTICS, http://www.bls.gov/cps/cps_htgm.htm\#unemployed (last visited Feb. 14, 2014) ("Persons are classified as unemployed if they do not have a job, have actively looked for work in the prior 4 weeks, and are currently available for work."). Accordingly, a liquidity shock from a job loss would have likely occurred in the quarter prior to the quarter in which it would be reflected in the unemployment rate. As it is necessary to examine the distribution of leverage as of the quarter prior to when the shock would be reflected in the unemployment rate, it is appropriate to use a one-period lag for unemployment because a two-period lag is used for measuring the distribution of leverage. results.

92. The state-level dummies used for a fixed effects model have been omitted from the 
Table 8: Default Rate \& Mean/Standard Deviation of Equity, Time-Series

\begin{tabular}{lcc}
\hline & \multicolumn{2}{c}{ Default Rate } \\
\cline { 2 - 3 } & \multicolumn{1}{c}{$\boldsymbol{\mu}$} & $\boldsymbol{\sigma}$ \\
\hline Standard Deviation of Equity (two-period lag) & -0.068 & $(0.028)^{*}$ \\
Mean Equity (two-period lag) & -0.163 & $(0.040)^{* *}$ \\
Unemployment Rate (one-period lag) & 0.832 & $(0.087)^{* *}$ \\
Constant Term & 0.114 & $(0.028)^{* *}$ \\
\hline$R^{2}$ & 0.71 & \\
$N$ & 165 & \\
\hline
\end{tabular}

As expected, states with lower mean equity were estimated to have statistically higher rates of default. Moreover, as predicted by our foregoing analysis, both the standard deviation of equity levels and their mean have a statistically significant effect on the default rate. The statistically significant negative coefficients estimated for both the mean and standard deviation of equity levels are consistent with our prediction that lower levels of overall equity that are tightly clustered together lead to higher rates of default. The coefficient for mean equity is larger than that of standard deviation, which makes sense: tightly clustered high levels of equity would not lead to default. Nonetheless, the statistically significant negative coefficients for standard deviation and mean equity suggest that low-equity clustering is an important predictor of the default rate.

An alternative regression measures the association between the proportion of homeowners with less than $20 \%$ equity and the default rate during the crisis period. This is another way to measure low-equity clustering because it reflects the greater concentration of homeowners at a relatively low level of equity. However, the usefulness of this measurement is limited because unlike the standard deviation, the proportion alone implies nothing as to the distribution of such equity within this less-than-20\% bin. Moreover, its causal significance is unclear: it might merely reflect declining home prices over time rather than represent a true predictor of increased default. Yet it can serve as a heuristic demonstration of the association between one form of low-equity clustering and the default rate.

The results of this regression are as follows: 
Table 9: Default Rate \& Proportion of Homeowners Less Than $20 \%$ Equity, Time-Series

\begin{tabular}{lcc}
\hline & \multicolumn{2}{c}{ Default Rate } \\
\cline { 2 - 3 } & $\boldsymbol{\mu}$ & $\boldsymbol{\sigma}$ \\
\hline Proportion of Homeowners $<20 \%$ Equity (two-period lag) & 0.105 & $(0.033)^{* *}$ \\
Unemployment Rate (one-period lag) & 0.883 & $(0.118)^{* *}$ \\
Constant Term & -0.013 & $(0.014)$ \\
\hline$R^{2}$ & 0.57 & \\
$N$ & 165 & \\
\hline
\end{tabular}

As expected, the proportion of homeowners with less than $20 \%$ equity has a statistically significant association with the default rate, even after controlling for unemployment. Its coefficient is positive, implying that a having higher proportion of homeowners in this low-equity bin leads to an increase in the default rate. As with the prior regression, this is a fixed effects model measuring within-group variation, and the state-level individual dummies have been omitted.

To summarize, notwithstanding the associational nature of this statistical analysis, our findings are consistent with the hypothesis that low-equity clustering is correlated with greater declines in housing prices and higher levels of mortgage default. Along with the studies surveyed in Section II.A, these empirical results suggest that low-equity clustering has a detrimental effect in times of crisis. In the following Part, we propose reforms to promote greater diversity in the distribution of home equity.

\section{Reforms to Promote Greater Diversity in the Distribution of Home Equity}

As suggested by theory and the above empirical results, low-equity clustering increases systemic risk in the housing market. Surprisingly, current policies such as the mortgage interest tax deduction and Federal Housing Authority (FHA) loans actually encourage low-equity clustering. In this Part, we critique these policies and suggest two distinct reforms to promote greater diversity in the distribution of home equity and improve the stability of the housing market: reforming the mortgage interest tax deduction and improving the Dodd-Frank Qualified Residential Mortgage definition. In the next Part, we discuss direct macroprudential regulation of the distribution of home equity. 


\section{A. Current Policies Increase Low-Equity Clustering}

\section{The Mortgage Interest Tax Deduction}

Much academic commentary has called for the repeal of the mortgage interest tax deduction. ${ }^{93}$ Critics have focused on the deduction's fundamental failure to promote homeownership, ${ }^{94}$ its regressive nature and non-utilization by taxpayers who could truly benefit from it, ${ }^{95}$ and its tendency to artificially inflate housing prices. ${ }^{96}$ More recent scholarship has emphasized that the credit may produce negative macroeconomic effects by incentivizing higher loan-tovalue ratios. $^{97}$ Through this lens, we can see that the synchronized clustering of homeowners in homes with low equity percentages is not merely the byproduct of independent action but is at least in part a predictable result of tax policy.

Under 26 U.S.C. Section 163(h), taxpayers may deduct interest paid on a mortgage utilized to acquire a home or secure a home equity loan. ${ }^{98}$ While the deduction is subject to a limit of a total mortgage balance of $\$ 1,000,000$ on acquisition debt and $\$ 100,000$ on home equity debt, there is no cap on the deduction nor is the taxpayer limited to claiming it for only one home. Up to two residences may be included, making the mortgage interest deduction a particularly powerful incentive to acquire housing with debt. The mortgage interest deduction is skewed to favor higher-income taxpayers, both because

93. E.g., Roberta F. Mann, The (Not So) Little House on the Prairie: The Hidden Costs of the Home Mortgage Interest Deduction, 32 ARIZ. ST. L.J. 1347 (2000) (calling for repeal of the mortgage interest deduction because of its tendency to encourage urban sprawl and deleterious effects on urban cities); Rebecca N. Morrow, Billions of Tax Dollars Spent Inflating the Housing Bubble: How and Why the Mortgage Interest Deduction Failed, 17 FordHAM J. CORP. \& FIN. L. 751,754 (2012) (calling for the repeal of the mortgage interest deduction as ineffective and contributing to overpriced housing as well as systemic instability); William G. Gale et al., Encouraging Homeownership Through the Tax Code, TAX NOTES 1171, 1171 (June 18, 2007) (advocating a "tax credit and a subsidized saving vehicle for first-time home buyers, financed by the elimination of the MID"); see also Edward L. Glaeser \& Jesse M. Shapiro, The Benefits of the Home Mortgage Interest Deduction, in 17 TAX POLICY AND THE ECONOMY 37, 81 (James M. Poterba ed. 2003) (finding that the mortgage interest deduction's "impact on the homeownership rate appears to be minimal"); Dennis J. Ventry, Jr., The Accidental Deduction: A History and Critique of the Tax Subsidy for Mortgage Interest, 73 LAW \& CONTEMP. PROBS. 233 (2010) (showing that the mortgage interest deduction lacked an intentional policy purpose).

94. See Glaeser \& Shapiro, supra note 93, at 37.

95. See GEORGE MCCARTHY ET AL., THE ECONOMIC BENEFITS AND COSTS OF HOMEOWNERSHIP: A CRITICAL ASSESSMENT OF THE RESEARCH 3 (2001) (summarizing the literature and concluding that " $[\mathrm{t}] \mathrm{ax}$ reforms beginning in 1986, however, raised the standard deduction and ... negated the tax advantages of ownership for most lower- and moderate-income households"); Morrow, supra note 93 , at 760 .

96. See Morrow, supra note 93, at 771-74.

97. See MCCARTHY ET AL., supra note 95, at 38-39 (describing how the mortgage interest deduction encourages homeowners to maintain high loan-to-value ratios); Morrow, supra note 93 , at $775-77$.

98. 26 U.S.C. $\$ 163(\mathrm{~h})(3)(2012)$. Refinancing debt not exceeding the original principal balance is expressly included within the scope of the deduction. $I d . \S 163(\mathrm{~h})(3)(\mathrm{B})(\mathrm{i})(\mathrm{II})$. 
deductions are allowed on up two residences, ${ }^{99}$ and because the value of the deduction is higher for high-income taxpayers who face higher marginal tax rates. ${ }^{100}$

Several features of the deduction encourage low-equity clustering. The value of the deduction increases with the amount of home mortgage interest paid in a given year. This creates an incentive for borrowers to maximize loanto-value ratios in order to realize the benefit from the deduction. More precisely, it is rational for borrowers to substitute any other debt for home mortgage debt as long as the difference between the interest cost of the other debt and that of the home mortgage debt is less than the net benefit from the deduction. ${ }^{101}$ As secured debt, home mortgages generally have lower interest rates than unsecured debt, suggesting that it will generally be in the borrower's interest to substitute home mortgage debt for all other debt. ${ }^{102}$

Indeed, the potential for the mortgage interest deduction to increase lowequity clustering is supported by the studies on equity extraction during the recent housing bubble. ${ }^{103}$ All three methods of extracting equity-cash-out refinancing, home equity loans, and purchasing a substitute home with a higher loan-to-value ratio ${ }^{104}$-could lead to additional deductible interest. In light of the widespread equity extraction that occurred across the United States in the run-up to the financial crisis, it is entirely reasonable to conclude that the mortgage interest deduction played a contributing role in encouraging homeowners to take on additional mortgage debt and thereby "ratchet up" their leverage to the highest possible level. ${ }^{105}$

One might object to this argument on the grounds that it is overly myopic: over the long term, homeowners will eventually pay off their mortgages and thereby reduce the amount of deductible interest. Nonetheless, as currently constituted, the home mortgage deduction perversely gives larger subsidies to taxpayers who borrow not only with lower initial equity but also with lower or no amortization in the future. Mortgagors receive larger deductions if they take out interest-only loans or if they repeatedly cash out equity in ways that preserve large interest deductions. Therefore, as currently structured, the home

99. This can lead to portfolio misallocation. $C f$. Majorie Flavin \& Takashi Yamashita, Owner-Occupied Housing and the Composition of the Household Portfolio, 92 AM. ECON. REV. 345 (2002) (arguing that homeowners overinvest in housing).

100. See Morrow, supra note 93, at 758 .

101. Such substitution can also amplify homeowners' natural tendency to overinvest in housing. Cf. Flavin \& Yamashita, supra note 99 , at 345.

102. Indeed, while the mortgage interest deduction is limited to refinances equal to or less than the prior mortgage balance, a borrower may continue to enjoy the benefit of the deduction through home equity loans or by obtaining a new acquisition loan (by buying a substitute home), which would be fully deductible up to the $\$ 1,000,000$ principal limit.

103. Greenspan \& Kennedy, supra note 65; Khandani et al., supra note 69.

104. See Greenspan \& Kennedy, supra note 65 , at 122; Greenspan \& Kennedy, supra note 70 , at 5-6.

105. See Khandani et al., supra note 69 , at 3. 
mortgage interest deduction gives homeowners an incentive on the margin to take out terms that increase systemic risk.

\section{Government-Insured Mortgages}

Another existing policy that fosters low-equity clustering is governmentinsured mortgages such as FHA loans. FHA loans are offered pursuant to section 203 of the National Housing Act, ${ }^{106}$ which empowers the Secretary of Housing and Urban Development to insure mortgages that conform to a set of statutory criteria, including principal limits and amortization requirements. ${ }^{107}$ Most importantly, the statute allows for down payments as low as $3.5 \% .^{108}$ Moreover, when marketing FHA loans, the Department of Housing and Urban Development has emphasized that "most of your closing costs and fees can be included in the loan," "109 suggesting that the purchaser's initial equity level may actually be lower than $3.5 \%$.

While the FHA loan program is well known, it is not the only form of government mortgage insurance that permits extremely low down payments. Similar programs exist for specific groups of customers and offer even more generous down payment terms. For example, the U.S. Department of Veterans Affairs is authorized by statute to guarantee loans for veterans of up to $100 \%$ of the purchase price. ${ }^{110}$ The U.S. Department of Agriculture offers loan guarantees for purchasing rural housing with no down payment required. ${ }^{111}$

106. 12 U.S.C. $\S 1709$ (2012).

107. See id. $\S 1709$ (b) (establishing eight criteria for eligibility as an insured FHA loan: (1) lender is approved by the Secretary; (2) loan principal does not exceed certain limitations, generally $115 \%$ of the median single-family home price in the area and no more than $100 \%$ of the property being purchased; (3) maximum maturity within thirty to thirty-five years depending on whether insurance was procured; (4) satisfactory amortization provisions; (5) accrues interest; (6) amortizing payments applied to both principal and interest; (7) contains other terms conforming to the Secretary's guidelines; and (8) a minimum down payment of $3.5 \%$ ).

108. Id. $\S 1709$ (b)(9)(A) ("A mortgage insured under this section shall be executed by a mortgagor who shall have paid, in cash or its equivalent, on account of the property an amount equal to not less than 3.5 percent of the appraised value of the property or such larger amount as the Secretary may determine.").

109. Let FHA Loans Help You, U.S. DEP'T OF Hous. \& URB. DEV., http://portal.hud.gov/hudportal/HUD?src=/buying/loans (last visited Feb. 14, 2014).

110. See 38 U.S.C. $\S 3710$ (2012) (not providing for any loan-to-value limits); U.S. DeP'T OF VETERANS AFFAIRS, LENDERS HANDBOOK - VA PAMPHLET 26-7, at ch. $3 \S 3$, http://www.benefits.va.gov/warms/pam26_7.asp (last visited Feb. 14, 2014) ("Unlike other home loan programs, there are no maximum dollar amounts prescribed for VA-guaranteed loans. ... VA limits the amount of the loan to the reasonable value of the property shown on the NOV plus the cost of energy efficiency improvements up to $\$ 6,000$ plus the VA funding fee, with the following exceptions."). The guarantee provided for VA loans, however, is subject to a relatively tight cap. See 38 U.S.C. $\S$ 3703 (a)(1)(A)(IV) (2012) (limiting loans above $\$ 144,000$ to a guarantee of $25 \%$ of the loan); $2012 \mathrm{VA}$ County Loan Limits, U.S. DEP'T OF VETERANS AFFAIRS 1, http://www.benefits.va.gov/HOMELOANS/d ocs/Loan_Limits_2012_Dec_2011.pdf (last visited Feb. 14, 2014) ("For all counties other than those listed below, the $\overline{2} 012$ [Loan] Limit is $\$ 417,000$.").

111. These so-called "section 502 loans" are authorized by 42 U.S.C. $\S 1472$ (2012). Pursuant to the Department of Agriculture's regulations, loans guaranteed under the program "may be made for up to 100 percent of the appraised value or the cost of acquisition and any necessary 
Finally, Fannie Mae and Freddie Mac offer programs that encourage private lenders to make low down payment mortgage loans. ${ }^{112}$ Under the MyCommunityMortgage program, Fannie Mae purchases single-family mortgages with up to a $95 \%$ loan-to-value ratio with no minimum borrower contribution. ${ }^{113}$ Similarly, through the Home Possible Mortgage program, Freddie Mac offers a product with $95 \%$ loan-to-value ratio, and only $5 \%$ of the purchase price is required from borrowers. ${ }^{114} \mathrm{We}$ will return to the topic of beneficial reforms to Fannie Mae and Freddie Mac in Part IV.

Lax lending standards have led to serious solvency concerns for all of the above entities. Of course, Fannie Mae and Freddie Mac were large purchasers of the subprime mortgages that led to the recent financial crisis, which necessitated their seizure by the Treasury and subsequent government capitalization. ${ }^{115}$ Yet serious concerns have also been raised regarding the solvency of the FHA, as a 2012 audit valued its insurance fund at negative $\$ 13.48$ billion. ${ }^{116} \mathrm{~A}$ recent analysis places the blame squarely on low-down payment requirements and the prospect of falling home prices pushing more owners into negative equity:

development including those purposes in $\S 1980.310$, whichever is less." 7 C.F.R. $§ 1980.311$ (b) (2013) (for new and existing construction, respectively).

112. Despite having been created and authorized by statute, Fannie Mae and Freddie Mac are private companies. See, e.g., 12 U.S.C. $\$ 1455(\mathrm{~h})(2012)$ (providing that Freddie Mac "shall insert appropriate language in all of [its] obligations and securities ... clearly indicating that such obligations and securities ... are not guaranteed by the United States and do not constitute a debt or obligation of the United States or any agency or instrumentality thereof other than [Freddie Mac]."). However, scholars have repeatedly argued that they carry an implied government guarantee because of their fundamental role in the secondary mortgage markets. See, e.g., W. Scott Frame \& Lawrence J. White, Fussing and Fuming over Fannie and Freddie: How Much Smoke, How Much Fire?, 19 J. ECON. PERSPECTIVES 159, 164 (2005); David Reiss, The Federal Government's Implied Guarantee of Fannie Mae and Freddie Mac's Obligations: Uncle Sam Will Pick Up the Tab, 42 GA. L. REV. 1019 (2008). These arguments were vindicated when the Department of the Treasury seized Fannie Mae and Freddie Mac in September 2008 and announced its willingness to provide up to $\$ 200$ billion in capital to ensure stability in the mortgage markets. See James R. Hagerty et al., U.S. Seizes Mortgage Giants, WALL ST. J., Sept. 8, 2008, http://online.wsj.com/article/SB122079276849707821.html.

More importantly, Fannie Mae and Freddie Mac purchased mortgages at the behest of the U.S. government to further public policy goals. See Frame \& White, supra note 112, at 171-73 (discussing the ways in which Fannie Mae and Freddie Mac further government policy goals of encouraging the consumption of housing). Their low down payment programs thus reflect government policy, because Congress could direct Fannie Mae and Freddie Mac to cease offering these programs either directly via statute or as a condition for receiving government funding.

113. MyCommunityMortgage: Affordable Financing to Serve Low- to ModerateIncome Borrowers, FANNIE MAE, http://www.fanniemae.com/content/fact_sheet/mcm-product-matrix .pdf (last visited Feb. 14, 2014).

114. Home Possible: At-a-Glance, FrEDDIE MAC, http://www.freddiemac.com/learn /pdfs/mp/hp_glance.pdf (last visited Feb. 14, 2014).

115. See FIN. CRISIS INQUIRY COMM'N, supra note 11, at 122-25 (discussing the numerous purchases by Fannie Mae and Freddie Mac of subprime and Alt-A mortgages from 2000-2008 and concluding that "[t]he results would be disastrous for the companies, their shareholders, and American taxpayers").

116. Gretchen Morgenson, In an F.H.A. Checkup, a Startling Number, N.Y. TiMES, Dec. 1, 2012, http:/www.nytimes.com/2012/12/02/business/in-an-fha-checkup-a-startling-number.html. 
The FHA has burned through its reserves over the past three years as defaults mount on loans it guaranteed as housing markets deteriorated. FHA-backed mortgages are an attractive option for borrowers because they can make down payments as low as $3.5 \%$. But as home prices continue to fall, many of those borrowers have fallen underwater, where they owe more than their homes are worth and are at greater risk of default if they experience income shocks. ${ }^{117}$

Indeed, a congressional subcommittee recently passed the FHA Emergency Fiscal Solvency Act designed to strengthen the FHA's cash reserves. ${ }^{18}$ But the possibility of insolvency at the FHA is just an example of the broader system-wide risk posed by low-equity clustering. FHA loans facilitate low-equity clustering by making loans to any qualifying borrower at a fixed down payment of $3.5 \%$. Other government programs offer mortgage loans with no down payment. These programs directly undermine systemic stability in the housing market by contributing to low-equity clustering. Some rightfully object that ending these programs would "choke off credit and send home prices lower." 119 Yet the advantage of the licensing approach, which we will discuss in detail below, is that it is unnecessary to eliminate low down payment loans entirely. Indeed, recent efforts to raise minimum down payment levels to $20 \%$ cause more harm than good.

\section{B. Reforming the Home Mortgage Interest Deduction}

In this and the following Section, we address reforms to reduce low-equity clustering. This Section describes the possibility of modifying the home mortgage deduction itself. Instead of incentivizing low, continuing loan-tovalue ratios, the tax code should be revised to encourage amortizing loans. To qualify for the deduction under our first proposal, ${ }^{120}$ a mortgage at the time of origination must satisfy three conditions:

(a) 5\% Down Payment Condition: the mortgage must have a combined loan-to-value ratio of no more than $95 \%$;

117. Nick Timiraos, Housing Agency's Reserves at Risk, WALL ST. J., Feb. 13, 2012, http://online.wsj.com/article/SB 10001424052970204795304577221222265037002.html.

118. See Subcommittee Approves Bills Improving Fiscal Health of FHA, Affordable Housing Programs, HOUSE COMM. ON FIN. SERV. (Feb. 7, 2012), http://financialservices.house.gov /News/DocumentSingle.aspx?DocumentID=278489.

119. See Timiraos, supra note 117 (noting that "many economists" believe this).

120. Ian Ayres and Joe Bankman have also recommended limiting the deduction to a new kind of qualifying mortgage. Ian Ayres \& Joe Bankman, Stop Subsidizing Risky Mortgages (2012) (unpublished manuscript) (on file with authors). 
(b) $30 \%$ DTI Condition: the mortgage must have no potential periodic payment that would exceed a debt-to-income (DTI) ratio of $30 \% ;^{121}$ and

(c) 30-year Repayment Condition: the mortgage schedule of payments must repay the principal and accrued interest within 30 years or before the borrower reaches 65 , whichever is sooner.

The first condition's requirement of minimal equity would be troubling if it were imposed by itself. Establishing a floor of 5\% might perversely induce more clustering than would occur in a world without a legal minimum. Housing and mortgage markets may be exposed to more risk of simultaneous defaults if homeowners concentrate at $5 \%$ equity than if some put $1 \%$ down, others put $5 \%$ down, and still others put $9 \%$ down. But the combination of the three conditions is minimally sufficient to start borrowers on an amortization path of increasing equity. As in the amortization era, the diachronic borrowing of successive cohorts of homeowners will be sufficient to induce beneficial diversity in home equity, as less recent borrowers will be more likely to have paid back part of their outstanding balance. These temporally staggered repayment schedules help mitigate the concern that equity requirements will induce clustering at the minimum.

The second DTI condition would exclude wildly uneven gyrations in payments that would threaten to outstrip the borrower's ability to pay. Under this second condition, the maximum of any prospective required periodic payment under the mortgage terms could not be more than $30 \%$ of the borrower's periodic income at the time of the loan origination. This "life-of-the loan" DTI condition would effectively prohibit balloon mortgages, because the required balloon at the end of the mortgage would be more than $30 \%$ of what the borrower's monthly income was at the time of origination. The DTI condition would also disqualify mortgages with initial teaser rates that ultimately reset to higher rates with associated payments that violated the $30 \%$ DTI cap. The DTI condition would not disqualify all adjustable-rate mortgages, but to qualify, the adjustable-rate mortgages would need to include interest rate caps that assured that the monthly mortgage payments would not exceed $30 \%$ of what the borrower's monthly income was at the time of origination.

The DTI condition does not guarantee that mortgagors will be able to make their monthly payments. There is, for example, still the risk that borrowers will be laid off in an economic downturn. But making sure that the maximum required mortgage payments fall below $30 \%$ of the borrower's income at time of origination helps assure that the borrower will not need to refinance solely because the mortgage terms allow for an unsustainable rise in

121. With regard to the Dodd-Frank QRM proposal, the mortgage must not have any potential periodic payment that would exceed the 30\% DTI cap based on the current schedule of payments. See infra Section III.C. 
mortgage payments. Qualifying mortgages do not eliminate systemic risk, but they help assure that risk is not exacerbated by artificially forcing borrowers to refinance during times of economic turmoil.

More broadly, to satisfy both the DTI condition and the 30-year repayment condition, mortgage repayment schedules will need to amortize repayments on a fairly continuous basis. Traditional 30-year fixed mortgages that satisfy the DTI condition with regard to the first monthly payment will a fortiori satisfy the condition with regard to all subsequent fixed payments. Loans would not, however, need to rigidly adhere to constant amortization. The possibility of temporary negative amortization, for example, as contemplated by once-a-year mortgage holiday provisions, would not be disqualifying so long as the remaining payments adhered to the $30 \%$ DTI requirement.

The idea behind the age limit in the third condition is to be more consistent with the life-of-the-loan DTI goal. A 60 -year-old who borrows on a 30 -year basis isn't likely to have the same income after reaching 70 or 80 . For couples, the rule might ask whether the DTI test is satisfied if we assume that income goes to zero when the older spouse hits 65. Macroprudentially, there might be higher risk with many 70 -year-old borrowers with loans that they can't repay (and can't refinance if we have another credit freeze-the beauty of a life-of-the-loan DTI test is that borrower never needs to go back to the refinancing market). The requirement that loans are paid off before retirement also is consonant with thinking of the mortgage deduction as a retirement account. And for those who wish to curtail the home mortgage interest tax expenditure, it would also have the advantage of cutting off the deduction for more elderly borrowers.

An important limitation of the three foregoing conditions, however, is that they do not respond to the untoward effects of equity stripping that can occur years after a mortgage has been issued. To respond to this problem, a fourth prerequisite might be added for homeowners to qualify for the deduction:

(d) Taxpayers who claim a home mortgage interest deduction with regard to a particular property must agree not to undertake any subsequent cashing out of amortized principal unless they have reached the age or established the kind of hardship that would analogously allow them to withdraw without penalty from a 401(k) account.

This condition would subject any non-qualifying cashing out of accrued equity to a $20 \%$ penalty. Borrowers would be able to cash out excessive down payments (which exceeded the initial 5\% requirement), and borrowers would be able to cash out appreciation in the value of the underlying house, but borrowers would be penalized for cashing out any amortized repayment of 
principal (unless the borrowers satisfied the age or hardship requirements for 401(k) distributions). ${ }^{122}$ For example, imagine a home that was purchased for $\$ 100,000$ with the borrower placing $\$ 10,000$ down and borrowing $\$ 90,000$ with a 30-year fixed interest loan. After a number of years, imagine that $\$ 20,000$ of the principal had been repaid (so that a $\$ 70,000$ principal was outstanding), and imagine that the house had increased in value to $\$ 130,000$. Under the fourth condition, the homeowner would be able to cash out without penalty $\$ 35,000$ (the $\$ 30,000$ of home appreciation plus the $\$ 5,000$ of excessive initial down payment). However, the homeowner would incur a $20 \%$ tax if she went further and cashed out the $\$ 20,000$ of amortized interest (unless the homeowner could meet the statutory age or hardship requirements for $401(\mathrm{k})$ distributions). ${ }^{123}$ This $20 \%$ cash out penalty is analogous to the $20 \% 401(\mathrm{k})$ early distribution penalty. Psychologically, the goal is to have homeowners start thinking of their home equity as a retirement asset. Under this modified tax rule, the condition of the interest deduction is that taxpayers accept 401(k) limits on their equity saving.

The central purpose of the fourth condition is not, however, to promote retirement savings. It is instead to dampen the untoward macroeconomic impact of equity stripping. Homeowners could still accomplish equity stripping by selling their homes and cashing out their accumulated equity (and then buying a subsequent house with a $95 \%$ loan-to-value ratio), ${ }^{124}$ but the many homeowners who wish to stay put in their current houses would not be able to cash out their accumulated repayments of principal until they reached the required age (or unless they could establish legitimate hardship). The goal is to dampen the prevalence of homeowners who cash out equity before retirement to finance discretionary spending. ${ }^{125}$

This proposal for tax reform is not a command-and-control mandate. Homeowners would not be required to borrow using qualified mortgages. They simply would not be able to deduct interest if their mortgages were non-

122. See generally 401(k) Resource Guide - Plan Participants - General Distribution Rules, INTERNAL REVENUE SERV., http://www.irs.gov/Retirement-Plans/Plan-Participant,-Employee/40 1(k)-Resource-Guide---Plan-Participants---General-Distribution-Rules (last visited Feb. 14, 2014).

123. To implement the regulation, subsequent lenders would be prohibited from taking a security interest in the borrower's interest in the amortized principal. This would mean that subsequent lenders' claims would be subordinated to an unchanging original principal amount of $\$ 90,000$ even if the original principal had in fact been paid down.

124. It would be possible to go further and require that accrued equity $(\$ 20,000$ in the previous example) would need to be rolled into any subsequent house as an additional pre-requisite of taking an interest deduction.

125. While Ayres \& Bankman, supra note 120 , consider the fourth proposal, they ultimately reject it because of the potential difficulty of implementation. The first three conditions can be assessed at the moment of origination. The fourth needs to be evaluated at the moment of any nonacquisition secured lending that contemplates cash-out to a borrower who has previously been taking deductions on the property. A more stringent condition would apply a $20 \%$ tax penalty to all cash-out refinances that did not meet the age or hardship requirements-thus prohibiting mortgagors from cashing out excessive down payments or capital appreciation. 
qualifying. Limiting the deduction to qualifying loans would help assure that the government eliminates subsidies for the kinds of mortgage terms that exacerbate systemic risk. Even without the tax subsidy, some homeowners might deleteriously choose to cluster in low down payment, interest-only loans. And notwithstanding the penalty, taxpayers who have taken an interest deduction may deleteriously choose to engage in equity stripping. But the hope is that these financial nudges may be sufficient to induce homeowners to make borrowing decisions that in aggregate reduce systemic risk.

\section{Reforming the Dodd-Frank Risk-Retention Proposal}

Dodd-Frank's risk-retention mechanism can be seen as an attempt to nudge the mortgage market away from low-equity clustering, but it does so by giving lenders incentives to originate loans that in aggregate will produce less systemic risk. Under 15 U.S.C. $\$ 780-11$, the "federal banking agencies"126 are directed to issue regulations requiring the issuers of asset-backed securities to retain $5 \%$ of the credit risk of assets that are "transferred, sold, or conveyed through the issuance of an asset-backed security by the securitizer." 127 The Senate Committee Report on the Dodd-Frank Act noted that the purpose of the credit risk-retention requirements was to "align [securitizers'] economic interests with those of investors in asset-backed securities." 128 Indeed, credit risk-retention requirements have the positive effect of giving securitizers "a strong incentive to monitor the quality of the assets they purchase from originators, package into securities, and sell.",129

However, the statute expressly exempts "qualified residential mortgages" ("QRMs") from credit risk-retention requirements. ${ }^{130}$ Requiring originators to retain merely $5 \%$ of their non-QRM originations does not at first blush seem like a very strong incentive. But for originators who had been using the securitization market to relend the same capital hundreds of times, ${ }^{131}$ the inability to reuse $5 \%$ of non-QRM originations might pose a major constraint. Under Dodd-Frank, there can only be $\$ 20$ of non-QRM loans for every $\$ 1$ of originator capital.

126. This term is defined as the "Office of the Comptroller of the Currency, the Board of Govemors of the Federal Reserve System, and the Federal Deposit Insurance Corporation." 15 U.S.C. $\S 780-11(\mathrm{a})(1)(2012)$.

127. E.g., id. $\S 78 \mathrm{o}-11(\mathrm{c})(1)(\mathrm{B})(\mathrm{i})(\mathrm{I})$. This phrase also appears in id. $\S 78 \mathrm{o}-$ $11(\mathrm{c})(\mathrm{l})(\mathrm{B})(\mathrm{i})(\mathrm{II})$ and $i d . \S 78 \mathrm{o}-11(\mathrm{c})(1)(\mathrm{B})(\mathrm{ii})$.

128. S. REP. NO. 111-176, at 129 (2010).

129. Id.

130. E.g., 15 U.S.C. $\$ 780-11($ c)(1)(B)(i)(I) (2012) ("The regulations prescribed under subsection (b) shall . . . require a securitizer to retain not less than 5 percent of the credit risk for any asset that is not a qualified residential mortgage that is transferred, sold, or conveyed through the issuance of an asset-backed security by the securitizer ....").

131. See Kathleen C. Engel \& Patricia A. McCoy, Turning a Blind Eye: Wall Street Finance of Predatory Lending, 75 FORDHAM L. REV. 2039, 2044 (2007). 
The statute does not define a QRM but directs regulators to define the term while taking into account:

[U]nderwriting and product features that historical loan performance data indicate result in a lower risk of default, such as ... standards with respect to the residual income of the mortgagor after all monthly obligations; the ratio of the housing payments of the mortgagor to the monthly income of the mortgagor; the ratio of total monthly installment payments of the mortgagor to the income of the mortgagor ....

On April 11, 2011, six financial regulators authorized by Dodd-Frank proposed a rule containing a multi-factored QRM definition that restricts both loan terms and borrower credit history characteristics. ${ }^{133}$ To qualify under the proposed rule, the terms of a residential mortgage must:

(a) Be a first lien loan with scheduled repayment of principal and interest within 30 years;

(b) Not have less than $20 \%$ down payment;

(c) Not allow negative amortization or deferred payment of interest or principal;

(d) Not allow a scheduled payment that is more than twice as large as any earlier payment;

(e) Not allow an increase in interest of more than $2 \%$ in any year and more than $6 \%$ over the life of the loan;

(f) Not allow points and fees of more than $3 \%$ of the total loan amount; and

(g) For the first five years, not allow a debt-to-income ratio of more than $28 \%$ and a total debt-to-income ratio of more than $36 \%$. ${ }^{134}$

These multi-factored tests are an admirable attempt to make progress on the twin problems of consumer and financial stability protection. This riskretention nudge indirectly incentivizes lenders to require larger down payments

132. 15 U.S.C. $\$ 780-11(\mathrm{e})(4)(B)(2012)$.

133. See Credit Risk Retention Proposed Rules, 76 Fed. Reg. 24,090, 24,121 (Apr. 29, 2011) (proposed by the Office of the Comptroller of the Currency, Federal Reserve Board, FDIC, SEC, FHFA, and HUD). The proposed rules define a series of "derogatory factors" that would disqualify a borrower from obtaining a qualified residential mortgage, including: (a) not currently thirty or more days past due on any obligation; (b) never sixty or more days past due on any prior obligation within the past 24 months; and (c) not have "been a debtor in a bankruptcy proceeding, had property repossessed or foreclosed upon, engaged in a short sale or deed-in-lieu of foreclosure, or been subject to a Federal or State judgment for collection of any unpaid debt" within the past thirty-six months. Id. For a detailed analysis of the proposed rules governing the new credit risk retention requirements under the DoddFrank Act, see Securitization After Dodd-Frank: A Look at the Proposed Risk Retention Rules, SIMPSON THACHER (Apr. 7, 2011), http://www.stblaw.com/content/Publications/pub1 185.pdf. 2011).

134. Credit Risk Retention Proposed Rules, 76 Fed. Reg. 24,090, 24,121 (Apr. 29, 
and more consistent amortization. The "twice as large" limitation effectively disqualifies all balloon loans and the interest adjustment caps limit the impact of teaser rates to artificially induce refinancing at the loan reset time. Still, we find that the proposed rule is needlessly harsh on some of its requirementsespecially the $20 \%$ down payment requirement--while perversely lax with regard to other requirements-especially the 5-year DTI limitation. This Section will suggest ways to modify the proposed rule to correct for these errors.

We begin by looking more closely at the down payment mandate. Even though down payment prerequisites were not mentioned in the statute, the proposed rule requires a minimum down payment of $20 \%$ of the market value or purchase price of the property, whichever is lower. ${ }^{135}$ The proposed qualified residential mortgage exemption responds to the problem of low-equity clustering discussed above. ${ }^{136}$ A $20 \%$ minimum might cause a clustering at $20 \%$, but that level of initial equity is sufficiently high that the concern that normal fluctuations in housing prices would cause a synchronized waive of defaults is remote. The $20 \%$ buy-in requirement is akin to a 99 -year flood levy, which will only rarely fail.

The problem, however, is that like an overly protective flood levy, such a large down payment requirement can impose a substantial burden on borrowers who are creditworthy but unable to accumulate sufficient funds. Indeed, the proposed rules prompted an outcry among consumer advocates and trade associations, who emphasized the immense harm that such a high standard would cause to creditworthy borrowers who have historically benefited from lower down-payment requirements. For example, the National Association of Realtors presented a study showing that "it would take more than a decade for the median American family to save enough for a $20 \%$ down payment on even a modest home."137 Moreover, an analysis by the Coalition for Sensible Housing Policy found that imposing a fixed minimum down payment requirement of $20 \%$ would "knock[] 15 to 20 percent of borrowers out of QRM

135. See id. The regulators also expressly rejected financing closing costs to circumvent these down payment requirements, citing Austin Kelly, Skin in the Game: Zero Down Payment Mortgage Default, 17 J. OF HouSING RES. 75 (2008) (linking increased default to low equity levels).

136. Interestingly, FHA-insured and other government-insured mortgages are excluded from the credit risk retention requirements. See 15 U.S.C. $\S 780-11(\mathrm{e})(3)(B)(2012)$. In light of the low down payment requirements for the loans, it appears that the rules are actually creating an incentive to shift the credit risk for low down payment mortgages onto the government's balance sheet rather than the private sector's. This has its own potentially negative implications, for it is far from clear that the government is better at managing low-equity credit risk than private lenders. $C f$. Timiraos, supra note 117 (describing serious concems over the solvency of the FHA). The licensing regime proposed infra Section IV.A would permit licenses to be traded, thus facilitating ownership of low-equity loans by the party best able to manage this credit risk.

137. Proposed Qualified Residential Mortgage Definition Harms Creditworthy Borrowers While Frustrating Housing Recovery, COAL. FOR SENSIBLE HOUS. POL'Y 12 (2011), http://www.realtor.org/wps/wcm/connect/b4ff208047d10e558blacb93a9f011 da/Coalition_For_SHP_W hite_Paper_August-1-2011.pdf (presenting study by the National Association of Realtors). 
eligibility, with only small improvement in default performance of about eighttenths of one percent on average." 138 While there might be a greater benefit to higher equity levels than the Coalition is willing to concede, there is little reason to doubt its contention that a high fixed down payment requirement would impose a very real cost.

These conclusions are supported by academic studies as well, which have found that higher LTV requirements decrease homeownership rates. ${ }^{139}$ Indeed, a recent study under the auspices of the University of North Carolina Center for Responsible Lending and the nonprofit Center for Responsible Lending concluded that the harm caused by such a high fixed down payment requirement far outweighs its benefits. ${ }^{140}$ Interestingly, the study found that the burden imposed by the qualified residential mortgage rule would fall disproportionately on minority and low-income borrowers. ${ }^{141}$ Utilizing loanlevel data from two proprietary databases, these researchers concluded that at the proposed fixed down payment level of $20 \%$, "the vast majority of borrowers-approximately 85 percent-would not have qualified for a QRM mortgage, with the impacts greatest for African Americans (93 percent) and Latinos (91 percent)." "42 Indeed, research has shown that these traditionally disadvantaged groups have already suffered disproportionately from the financial crisis. ${ }^{143}$ Denying creditworthy minorities and low-income borrowers the opportunity to own a home would increase inequality ${ }^{144}$ and deprive society

\section{Id. at 6 .}

139. See, e.g., Peter Linneman et al., Do Borrowing Constraints Change U.S. Homeownership Rates?, 6 J. HousING ECON. 318, 330 (1997) (describing the effect of increasing LTV ratios on changes in homeownership rates).

140. Roberto G. Quercia et al., Balancing Risk and Access: Underwriting Standards for Qualified Residential Mortgages, CTR. FOR CMTY. CAPITAL (2012), http://ccc.sites.unc.edu/files/2013/0 2/QRM_Underwriting.pdf.

141. Id. at 33-34.

142. Id. at 34 .

143. E.g., Katrin B. Anacker \& James H. Carr, Analysing Determinants of Foreclosure Among High-Income African American and Hispanic Borrowers in the Washington, DC Metropolitan Area, 11 INT'L J. HOUSING POL'Y 195 (2011) (showing that "high-income African-American borrowers are 36 per cent and Hispanic borrowers 79 per cent more likely to go into foreclosure"); Debbie Gruenstein Bocian et al., Foreclosures by Race and Ethnicity: The Demographics of a Crisis, CTR. FOR RESPONSIBLE LENDING (2010), http://www.responsiblelending.org/mortgage-lending/research-analysis /foreclosures-by-race-and-ethnicity.pdf (arguing that African-American and Latino borrowers disproportionately suffered from foreclosure from 2007 through 2009); Debbie Gruenstein Bocian et al., Lost Ground, 2011: Disparities in Mortgage Lending and Foreclosures, CTR. FOR RESPONSIBLE LENDING (2011), http://www.responsiblelending.org/mortgage-lending/research-analysis/Lost-Ground -2011.pdf (examining 27 million mortgages and finding that "borrowers of color are more than twice as likely to lose their home as white households").

144. The gap between whites and persons of color has grown substantially since the onset of the financial crisis. See, e.g., Paul Taylor et al., Twenty-to-One: Wealth Gaps Rise to Record Highs Between Whites, Blacks and Hispanics, PEW RESEARCH CTR. (2011), http://www.pewsocialtrends.org/files/2011/07/SDT-Wealth-Report_7-26-11_FINAL.pdf. While home prices have fallen since the onset of the crisis, homeownership has historically led to greater wealth among low-income households compared to renting over the long-term. See, e.g., Michael A. Stegman et al., The Wealth-Creating Potential of Homeownership: A Preliminary Assessment of Price 
of the positive externalities resulting from increased homeownership. ${ }^{145}$ Moreover, the reduced demand resulting from such a rule might well depress housing prices even further, destroying wealth for millions of white homeowners (and possibly causing additional defaults) as well.

While we view the $20 \%$ down payment requirement to be too severe, it at least furthers the regulatory project of reducing systemic risk. More bizarre to us is the regulation's 5-year limitation on its DTI requirement. Like our proposed modification to the home mortgage interest deduction, the DoddFrank risk-retention proposal disqualifies any mortgage where the maximum payment pursuant to the mortgage provisions exceeds $28 \%$ of the borrower's income at the time of the loan origination. As discussed earlier, a DTI requirement (combined with the 30-year repayment requirement) goes a remarkably long way in inducing fairly continuous amortization of the outstanding principal-and eliminates balloon and interest resets that create payment obligations beyond borrowers' means. But without explanation, the proposed regulations limit the DTI requirement to only the first five years of mortgage payments. Under the proposed regulation, there is nothing to stop a mortgage from having a 5-year reset that doubles the payment to an unsustainable DTI of $56 \%$. ${ }^{146}$ Thus, the proposed QRM definition allows the very kind of payment resets that can force borrowers to refinance. Recent experience teaches that when a substantial number of borrowers have to simultaneously refinance because of these resets, housing and mortgage markets can be exposed to increased volatility.

The center of our proposal is to suggest that the DTI requirements be applied to all of the loan payments. The proposal is straightforward to implement and indeed can be accomplished by merely deleting eighteen words from the proposed regulation. ${ }^{147}$ Unlike the down payment requirement,

Appreciation Among Low-Income Homebuyers, in CHASING THE AMERICAN DREAM: NEW PERSPECTIVES ON AFFORDABLE HOMEOWNERSHIP (William M. Rohe \& Harty L. Watson eds., 2007).

145. There is a vast body of scholarship examining the social benefits of homeownership. A seminal study on the topic is Denise DiPasquale \& Edward L. Glaeser, Incentives and Social Capital: Are Homeowners Better Citizens?, 45 J. URB. ECON. 354 (1999), which found that homeownership leads to higher levels of citizenship and social capital as a result of decreased mobility compared to renting. However, there are potential endogeneity problems with this approach, and a recent study of low-income homeowners utilizing a field experiment called into question some of these conclusions. Gary V. Engelhardt et al., What are the Social Benefits of Homeownership? Experimental Evidence for Low-Income Households, 67 J. URB. ECON. 249 (2010). Nonetheless, this study arrived at no conclusive findings regarding most of the benefits of homeownership. See id. at 255 ("Our clearest set of results is for the impact of homeownership on political involvement . . . For most of the other outcomes, the results are not conclusive."). It was also limited in duration to four years, leading its authors to emphasize that "the results provide estimates of the short-term effects of homeownership on social capital and local amenities, but not long-term effects." Id. at 256.

146. The "twice as large" requirement operates independent of the DTI requirement and is not limited to the first five years of payments.

147. Specifically by eliminating "during the first five years after the date on which the first regular periodic payment will be due" from Credit Risk Retention Proposed Rules, 76 Fed. Reg. 24,090, 24,126 (Apr. 29, 2011). 
applying the DTI requirement to all scheduled payments would not preclude credit-worthy borrowers from obtaining financing. As with our home-mortgage interest deduction proposal, it would only move borrowers toward mortgages that capped the maximum interest rate at an amount that was within the borrowers' means. ${ }^{148}$

A second modification that mirrors our home-mortgage interest deduction would be to disqualify cash-out refinancing transactions. The current QRM excludes second-lien mortgages and thus already impedes one loan type that has been used to facilitate equity stripping. But the current QRM does not disqualify non-acquisition transactions in which a borrower replaces initial acquisition loans with a higher-balance first lien loan and in so doing cashes out the difference in principle. As discussed above, equity stripping by large segments of mortgagors almost certainly exacerbated the housing crisis. Adding a no-cash-out requirement to the QRM definition will not have the exclusionary effect on home acquisition of the $20 \%$ down payment requirement, but will help reduce systemic risk by increasing the likelihood that different cohorts of mortgagors will have different amounts of accrued equity.

If the 5-year limitation to the DTI requirement is removed and a no-cashout requirement is added, it should be possible to lower the down payment requirement to a less exclusionary 5 or $10 \%$ level. Indeed, a thoroughgoing DTI requirement (combined with the 30 -year repayment requirement) would substantially simplify the QRM definition. For example, the "no negative amortization" requirement is not necessary in a world where the DTI requirement is applied to all potentially required payments. From the standpoint of systemic volatility, we need not prohibit temporary negative amortizationso long as it is not sufficient to drive the DTI beyond the point of sustainability. Similarly, the requirement that no scheduled payment be more than twice as large as any earlier payment is not necessary in the shadow of an enhanced DTI requirement. Initial teaser rates less than half of the long-term rate are not a problem from the standpoint of systemic risk as long as the long-term rate is within the borrower's ability to pay. ${ }^{149}$ Overall, a modified version of the QRM definition with reduced down payments, a DTI requirement that applied for the life of the loan, and a prohibition of cash-out transactions would have a much smaller exclusionary impact on low-income borrowers, but still provide strong lender incentives to put borrowers on a path toward amortizing equity. ${ }^{150}$

148. Alternatively, the DTI requirement might only be suspended after the latter of five years or when the borrower has acquired at least $20 \%$ of the equity in the house. If the down payment requirement is reduced to $10 \%$, a borrower with a 30 -year fixed mortgage with $7 \%$ APR would only reach $20 \%$ equity after 8.33 years (and at a $10 \%$ APR, a borrower would only achieve a $20 \%$ equity position after 11.33 years).

149. Some of the QRM requirements - such as the 3\% cap on points and fees-might be retained, however, to paternalistically protect borrowers from being taken advantage of by loan originators.

150. At the time of writing, the federal agencies released a new QRM proposed rule, which incorporates some of the reforms we suggest in this Section. Credit Risk Retention, 78 Fed. Reg. 


\section{Direct Macroprudential Regulation of the Distribution of Equity}

This Part takes up a third, more direct approach: regulating the distribution of home equity at the macroprudential level. We delineate two proposals: (1) a system of tradable leverage licenses that would apply to mortgage origination nationwide; and (2) a new definition of "conforming mortgage" utilized by Fannie Mae and Freddie Mac. The former is a thought experiment that would directly shape the distribution of equity but requires substantial legislative action. The latter is a more implementable solution that does not require extensive statutory reform and operates by affecting the economic incentives of private mortgage lenders.

\section{A. A System of Tradable Leverage Licenses}

To demonstrate how substantial legislative reform could permit direct regulation of the distribution of home equity, in this Section we propose a system of tradable leverage licenses. In contrast to the foregoing borrower and lender incentives, a system of tradable leverage licenses would cap the number of high leverage loans at quantities pre-specified by regulators. By requiring that lenders obtain a license to originate mortgage loans, regulators can directly influence the distribution of equity at both the national level and in specific jurisdictions. Under our proposal, licenses would be contingent on three variables: year, place and leverage. As a precondition to originating a highleverage mortgage, a lender would need to obtain licenses (from the government or the tradable secondary market) for the jurisdiction, years, and minimum levels of equity contemplated by the loan repayment schedule. For concreteness, imagine a system that required licenses for four equity ranges:

\footnotetext{
57,928 (Sept. 20, 2013), http://www.gpo.gov/fdsys/pkg/FR-2013-09-20/pdf/2013-21677.pdf. Most significantly, they define QRM as identical to the CFPB's qualified mortgage (QM) standard, which has the effect of removing the minimum $20 \%$ down payment requirement. However, QM (and thus QRM) retains the five-year period for calculating DTI and does not prohibit cash-out refinances. See Ability-toRepay and Qualified Mortgage Standards under the Truth in Lending Act, 12 C.F.R. $\S 1026.43(\mathrm{e})(1)$ (i) (2013). While we welcome the elimination of the overly broad $20 \%$ minimum down payment threshold, as we explain in this Section both the five-year DTI calculation and the ability to engage in cash-out refinancing contribute to equity stripping and thus facilitate low-equity clustering. Moreover, there is no need to limit the regulatory response to one of two extremes of either a heavy-handed $20 \%$ minimum (prior QRM proposal) or no down payment requirement (new QRM proposal). By not regulating equity levels at all, the new QRM rule fails to address the substantial threat to systemic stability posed by lowequity clustering. As we suggest in Section IV.A, a system of leverage licensing allows some limited quantity of low-down payment mortgages while preventing excessive clustering of low-equity loans.
} 
Table 10: Example Distribution of Leverage Licenses

\begin{tabular}{ll}
\hline Equity Range & Quantity of Licenses* \\
\hline Less than $5 \%$ & $1 \%$ \\
Less than $10 \%$ & $5 \%$ \\
Less than $20 \%$ & $20 \%$ \\
Less than $30 \%$ & $30 \%$ \\
\hline
\end{tabular}

*Quantity expressed as a percentage of residential homes in jurisdiction.

A lender who wanted to originate a zero down payment, thirty-year fixed $8 \%$ rate mortgage would need to obtain jurisdiction-specific licenses at the time of origination for the future years in which the mortgage would fall into specified equity ranges. In this specific example, the lender would need to obtain "Less than 5\%" licenses for the first five years, "Less than $10 \%$ " licenses for years six through nine, "Less than $20 \%$ " licenses for years ten through fourteen, and "Less than 30\%" licenses for years fifteen through eighteen. ${ }^{151}$

By requiring the lender to obtain a series of year-specific and jurisdictionspecific licenses, regulators could help assure that at any moment in time, there were no more than a certain percentage of high-leverage loans in a particular housing market. Year-specific licenses also allow market participants more flexibility in offering different repayment schedules. Mortgages with larger down payments or shorter amortization periods would require licenses for fewer years. On the other hand, interest-only mortgages or adjustable-rate mortgages with the possibility of large increases in mortgage payments would tend to require more licenses as the loan potentially lingered at higher levels of equity for more years. ${ }^{152}$ In a world with a limited quantity of year-specific leverage licenses, regulators need not prohibit zero percent down payment interest-only loans in order to manage systemic risk. They only need limit the number of such high default risk loans to an amount that the specific housing market can be expected to absorb.

Our licensing proposal only regulates the expected level of leverage that would obtain if the underlying home value remains level after origination. Negative shocks to housing prices can produce increased leverage notwithstanding lender compliance with ex ante licensing. For example, a mortgage that originated with a $5 \%$ down payment would not need "Less than $5 \%$ " licenses for any repayment year. But after the mortgage issued, a decrease in housing prices could cause the homeowner to in fact have less than $5 \%$ equity in her house. Like our earlier proposed regulations of DTI (which

151. In contrast, if the borrower made a $10 \%$ down payment and borrowed the remainder with a thirty-year fixed $8 \%$ mortgage, the lender would need to obtain no "Less than $5 \%$ " or "Less than 10\%" licenses, and instead would need to obtain "Less than $20 \%$ " licenses for years one through ten, and "Less than $30 \%$ " licenses for years eleven through fifteen.

152. For example, a thirty-year adjustable rate mortgage that allowed the interest to increase to a $12 \%$ APR would require "Less than $5 \%$ " licenses for the first nine years of the loan. 
assumed constant debtor income), the leverage licenses regulations would assume constant home values. Our licensing proposal accordingly does not eliminate systemic risk in the housing market, but it does ensure that homeowners have a more resilient distribution of equity going into a housing price downturn.

Going beyond the nudges of the last two Sections and directly regulating the maximum number of high leverage loans allows regulators to streamline other aspects of the regulation. Our previous buyer and lender incentive proposals regulated aspects of the transactions that might force borrowers to return to the lending market to refinance their mortgages because of a balloon or possibility of payments being reset to unsustainable DTIs. As argued above, clusters of mortgages with these balloons and reset provisions exacerbated the impact of normal fluctuations in housing prices, because lenders were unlikely to refinance loans that had home values less than the outstanding principal. We limited our qualifying mortgage definitions in both our tax-deduction and riskretention proposals to eliminate this underwater-refinancing risk. But this refinancing risk is less of a concern in a world of leverage licensing because there would be a limited number of underwater mortgages. To take an extreme example, imagine that $100 \%$ of homes have a substantial balloon payment that is due December 31,2020, and that homeowners are maximally leveraged going into 2019 , taking full advantage of allowable licenses. ${ }^{153}$ Imagine further that during the course of 2019 , housing prices fall by $8 \%$. When the balloon payments become due, the lending market will be unlikely to lend to borrowers who have less than $8 \%$ equity at the beginning of 2019 - but there will only be $6 \%$ of homeowners who will fall into this category. Instead of eliminating terms that might require refinancing, the leverage licensing works by limiting the number of underwater refinancers. ${ }^{154}$ The underwater mortgagors who could not refinance would (as in the recent crisis) be forced to default on their original loans. But the scope of defaults by design would be limited to a number that could more likely be absorbed by the market without inducing a further deterioration in housing prices.

As these licenses are tradable, a secondary market would permit their acquisition by the bidders who value them most. Because licenses would be separately obtained by lenders, the licensing requirement would not complicate borrowers' decision making. Regulators would monitor the distribution of

153. Thus, $1 \%$ of homeowners would have no equity in their homes, $5 \%$ of homeowners would have $5 \%$ equity in their homes, $20 \%$ of homeowners would have $10 \%$ equity in their homes, and $30 \%$ would have $20 \%$ equity in their homes.

154. Even homeowners with positive equity may-after an $8 \%$ drop in housing prices-have to refinance with more leverage, which would require more additional licenses. In the foregoing example, $20 \%$ of homeowners might have had $10 \%$ equity before the $8 \%$ drop in housing prices, implying that they would need to refinance with just $2 \%$ down. The percentage of high-leverage refinancers might outstrip the number of available licenses. This example suggests circumstances where regulators in the midst of a downturn would need to expand the number of licenses available (or create refinance licensing exceptions) to allow such refinancing to occur. 
home equity through a reporting system and could issue additional licenses or buy back licenses in the open market to provide needed liquidity or to prevent low-equity clustering. Licenses could also further social policy goals, such as directing low-equity loans to minorities or needy communities. Finally, limited exemptions from the licensing requirement should be considered, along with methods of enforcement and ways of transitioning existing mortgages into the new regime.

\section{Why Licensing? The Advantages of Tradable Permits}

The starting point for this analysis is the recognition that from an economic perspective, low-equity clustering constitutes a negative externality because its social costs are not borne solely by the parties who take out or issue low-equity loans. ${ }^{155}$ Lenders who originate loans at low down payment levels enjoy the benefits of increased output but do not bear the consequences of the systemic instability imposed on society as a whole. While no literature has directly addressed the social cost of low-equity clustering from an economic policy perspective, ${ }^{156}$ much has been written on a highly analogous problem: regulating carbon emissions and other environmental hazards. There are many similarities between the two fields, but the essential commonality is that both activities serve a valuable social purpose in certain limited quantities. ${ }^{157}$ Indeed, as discussed above, systemic stability in the housing market would be improved by maintaining certain proportions of loans at differing levels of low equity while preserving sufficient "circuit breakers" to prevent a domino effect of cascading falling prices. ${ }^{158}$ Similarly, emissions are essential to industrial production and thus socially valuable in limited quantities. The regulatory challenge posed by both emissions and low-equity lending is to ensure that the market produces a reasonable quantity of output, not to ban the activity entirely. One hundred thousand zero-equity mortgages scattered throughout the United States would not substantially exacerbate systemic risk. The key

155. For a seminal discussion of externalities in the law and economics literature, see Ronald H. Coase, The Problem of Social Cost, 3 J. L. \& ECON. 1 (1960).

156. Some literature has addressed the danger of systemic risk posed by having so many borrowers with underwater mortgages by calling for principal modification programs. E.g., Gregory Scott Crespi, The Trillion Dollar Problem of Underwater Homeowners: Avoiding a New Surge of Foreclosures by Encouraging Principal-Reducing Loan Modificalions, 51 SANTA CLARA L. REV. 153 (2011); Eric A. Posner \& Luigi Zingales, A Loan Modification Approach to the Housing Crisis, 11 AM. L. \& ECON. REV. 575 (2009); Manuel S. Santos, How Home Loan Modification Through the 60/40 Plan Can Save the Housing Sector, 94 FED. RESERVE BANK OF ST. LOUIS REV. 103 (2012).

157. Prohibiting low-equity loans below a certain fixed down payment level would have devastating social consequences. See discussion supra Section III.C (criticizing the Dodd-Frank qualified residential mortgage standard for attempting to encourage fixed $20 \%$ down payment mortgage loans).

158. See discussion supra Section I.B. 
problem of the last crisis was that millions of these loans were concentrated in a few geographical markets. ${ }^{159}$

There have been several regulatory approaches to controlling environmentally harmful pollutants and emissions over the past century, which can shed light on the best method to regulate low-equity lending. The traditional regulatory model, often termed "command-and-control," sought to place the regulator in the role of directly instructing private actors as to acceptable and unacceptable activity. ${ }^{160}$ In the words of one advocate of this model in the context of environmental pollution, command-and-control means that "the government 'commands' pollution reductions (e.g., by setting emissions standards) and 'controls' how these reductions are achieved (e.g., through the installation of specific pollution-control technologies)." context of low-equity clustering, a command-and-control approach might involve setting lender-specific permissible equity levels and attempting to ensure that lenders comply with these standards, perhaps by requiring approval before individual loans are made or mandating reports of loan and equity levels on a per-lender basis. As discussed above, ${ }^{162}$ some mandates might exacerbate the clustering problem by inducing a substantial segment of borrowers to pool at a minimum required down payment percentage. There are numerous problems with a command-and-control approach, and it came under withering criticism throughout the second half of the twentieth century. ${ }^{163}$

In response to the inefficiency of the command-and-control model, economists advocated the adoption of so-called "market" systems, which achieved environmental regulatory goals by instituting economic incentives for private actors. ${ }^{164}$ Today, these approaches are widely accepted by economists as superior to the command-and-control model because these private incentives ensure that goods flow to their highest-valued use. For example, in the context of low-equity lending, a market-based system would permit lenders to pay a price to lend at certain equity levels, thus permitting those lenders who are

159. See supra Section II.A.

160. For a defense of command-and-control systems as worth considering in environmental regulation despite their unpopularity, see Daniel H. Cole \& Peter Z. Grossman, When Is Command-and-Control Efficient? Institutions, Technology, and the Comparative Efficiency of Alternative Regulatory Regimes for Environmental Protection, 1999 WIS. L. REV. 887.

161. Id. at 887 n.1.

162. See discussion supra Section III.B.

163. See, e.g., Bruce A. Ackerman \& Richard B. Stewart, Reforming Environmental Law, 37 Stan. L. REV. 1333, 1334 (1985); Richard B. Stewart, United States Environmental Regulation: A Failing Paradigm, 15 J. L. \& CoM. 585, 587-95 (1995).

164. Volumes have been written on the economic approach to environmental regulation. An influential survey of the initial empirical literature is found in T.H. Titenberg, Economic Instruments for Environmental Regulation, 6 OXFORD REV. ECON. POL'Y 17, 17 (1990) ("By changing the incentives an individual agent faces, the best private choice can be made to coincide with the best social choice. Rather than relying on the regulatory authority to identify the best course of action, the individual agent can use his or her typically superior information to select the best means of meeting an assigned emission reduction responsibility."). 
particularly well-positioned to provide low equity mortgages to serve customers at the lowest cost and most efficient output.

Nonetheless, there has been considerable debate over which of the two primary forms of market-based regulation of negative externalities is desirable: Pigouvian taxes or tradable permits. ${ }^{165}$ A Pigouvian tax is a tax imposed on the production of a good responsible for a negative social externality so as to induce the producer to reduce output to the socially optimal quantity. ${ }^{166} \mathrm{~A}$ tradable permit, on the other hand, directly regulates the overall industry-wide output of the good, but allows producers to allocate the desired quantity levels among themselves by trading on a secondary market. ${ }^{167}$ In a highly influential article, Marty Weitzman famously showed that there is no inherent advantage to either price or quantity controls because "in principle exactly the same information is needed to correctly specify either."168 However, he emphasized that there might be practical limitations that make tradable permits better than taxes in a given context: "[I]f . . . it is difficult or expensive to monitor output on a continuous scale but relatively cheap to perform a pass-fail litmus type test on whether a given output level has been attained or not, the price mode may be greatly disadvantaged from the start." 169

This is precisely the case with regulating low-equity lending. It is much simpler to cap the quantity and let the market set the price for low-equity clustering through tradable permits than to impose an optimal Pigouvian tax. For example, if regulators set the Pigouvian price of borrowing with no equity

165. For a brief overview of the leading views on this debate from an economic policy perspective, see Robert W. Hahn, Economic Prescriptions for Environmental Problems: How the Patient Followed the Doctor's Orders, 3 J. ECON. PERSP. 95 (1989). Economic literature traditionally favored Pigouvian taxes as the remedy of choice for negative externalities, particularly in the context of environmental regulation. See, e.g., ARTHUR PIGOU, THE ECONOMICS OF WELFARE (1932); William J. Baumol \& Wallace E. Oates, The Use of Standards and Prices for Protection of the Environment, 73 SWEDISH J. ECON. 42 (1971). Later scholars, however, emphasized the possibility of employing tradable permits, or quantity limitations that may be exchanged on a secondary market between producers. E.g., J. H. DALES, POLLUTION, PROPERTY AND PRICES (1968) (suggesting the notion of tradable "pollution rights"). A highly influential piece arguing in favor of the equality of tradable permits, if not their outright superiority in certain circumstances, is Martin L. Weitzman, Prices vs. Quantities, 41 REV. ECON. STud. 477 (1974). See also Robert Cooter, Prices and Sanctions, 84 ColuM. L. REv, 1523 (1984) (discussing the economic conception of law as a "set of official prices"). But see Robert N. Stavins, Transaction Costs and Tradeable Permits, 29 J. ENVTL. ECON. \& MGMT. 133 (1995) (arguing that the potential transaction costs of a tradable permit system are non-trivial and that it is essential to take these into consideration when comparing tradable permit models to more conventional approaches).

166. See generally PIGOU, supra note 165. Pigovian taxes are named after Pigou who was the first to suggest these taxes as a means to reduce output to the desired level.

167. See generally DALES, supra note 165 .

168. Weitzman, supra note 165 , at 478 . But see Cooter, supra note 165 , at 1531 (arguing that "behavior is more elastic with respect to prices than sanctions").

169. Weitzman, supra note 165 , at 479 n.3. But see Louis Kaplow \& Steven Shavell, On the Superiority of Corrective Taxes to Quantity Regulation, 4 AM. L. \& ECON. REV. 1 (2002) (arguing that well-designed tax schemes are superior to tradable permits). Kaplow and Shavell, however, emphasize that nonlinear corrective taxes are particularly suited for "the case of externalities generated by a single firm." Id. at 14 . Yet mortgage lending is conducted by numerous loan originators, suggesting that Kaplow and Shavell's argument is less convincing in this context. 
at, say, $\$ 2000$, it might be too low-millions of borrowers might pay this price, and the economy would again be exposed to the needless systemic risk caused by low-equity bunching. ${ }^{170}$

While a licensing regime does impose the administrative cost of monitoring the distribution of home equity and adjusting the issuance of new licenses to achieve desired system-wide equity goals, a tax-based system would require this entire apparatus in addition to a sophisticated calculation of the proper taxation amount that would bring about the desired quantity level. Even if such a tax could be computed accurately, a licensing approach is much more direct and saves considerable expense. Indeed, tradable permits have been proposed in a variety of similar contexts. ${ }^{171}$ Licenses are the best mechanism to regulate the distribution of home equity and combat low-equity clustering.

Under our "cap and trade" regime, regulators would cap the maximum amount and distribution of leverage in the system and then trade in the license market would determine the price of purchasing leverage. An advantage of the marketized system is not only that the low-equity loans flow to the highestvalue borrowers, but also that the cost of acquiring the licenses (which ultimately will be borne by borrowers) gives borrowers better incentives to borrow with repayment terms that promote systemic stability. Leverage licensing gives borrowers better micro-contracting incentives because borrowing with larger down payments or faster amortization would avoid the need for the most quantity-constrained licenses.

\section{Toward a New Regulatory Regime}

The regulatory regime proposed in this Article begins with subjecting the origination of residential mortgages, ${ }^{172}$ whether for an initial purchase or

170. An intermediate form of regulation with attributes of both price and quantity regulation would be to have Pigouvian taxes that increase with quantity. See generally Ian Ayres, Narrow Tailoring, 43 UCLA L. REV. 1781 (1996).

171. E.g., Ian Ayres \& Gideon Parchomovsky, Tradable Patent Rights, 60 STAN. L. REV. 863 (2007); David Berry, The Market for Tradable Renewable Energy Credits, 42 ECOLOGICAL ECON. 369 (2002); Kenneth M. Chomitz, Transferable Development Rights and Forest Protection: An Exploratory Analysis, 27 INT'L REG'L SCI. REV. 348 (2004); Douglas MacMillan, Tradeable Hunting Obligations-A New Approach to Regulating Red Deer Numbers in the Scottish Highlands?, $71 \mathrm{~J}$. ENVTL. MGMT. 261 (2004); Alan Randall \& Michael A. Taylor, Incentive-Based Solutions to Agricultural Environmental Problems: Recent Developments in Theory and Practice, 32 J. AGRIC. \& APPLIED ECON. 221 (2000); Ricardo Bayon, A Bull Market in ... Woodpeckers?, MILKEN INST. REV. 30 (Mar. 2002) http://www.milkeninstitute.org/publications/review/2002_3/30_39.pdf.

172. It is possible to apply the licensing regime to commercial loans as well. There is nothing in this framework that uniquely applies to residential mortgages. However, commercial buyers tend to be more sophisticated, and down payment requirements are usually much higher as a matter of course. See, e.g., Sylvia Rosen, Commercial Mortgages Buyers' Guide, BUYERzONE, http://www.buyerzone.com/finance/commercial-mortgages/bg-commercial-mortgage-borrowing-conside rations (last visited Feb. 14, 2014) ("Commercial lenders generally require $20 \%$ to $30 \%$ down payments."). Accordingly, it is less clear that the benefits from applying the licensing framework to commercial loans would outweigh the costs. 
refinancing transaction, to a mandatory licensing requirement. As under existing Truth-in-Lending disclosure laws, ${ }^{173}$ the licensing obligation would apply to mortgage originators, i.e. the counterparties signing the loan documents with the borrower. The legal mechanism for instituting the licensing requirement would be to enact a law mandating that for any mortgage or deed of trust securing a loan agreement for residential use, a lender must obtain in advance of origination leverage-specific and jurisdiction-specific licenses for the years in which the scheduled minimum amortization would produce equity percentages that fall within one of the four prescribed ranges: less than 5\%; less than $10 \%$ (and greater than or equal to $5 \%$ ); less than $20 \%$ (and greater than or equal to $10 \%$ ); and less than $30 \%$ (and greater than or equal to $20 \%$ ). Lenders' ownership of licenses would be registered in a public database, and a nonpublic supplement would also indicate whether each license was in use by identifying the address of the residence for which the license was used. ${ }^{174}$ Ideally, the mortgage deed would also contain the reference number of the requisite licenses in order to notify regulators and other third parties that the loan agreement was authorized. This deed disclosure would be particularly beneficial if contractual non-enforceability was utilized to ensure compliance with the licensing regime ${ }^{175}$ because third parties could rely on the absence of an authenticated licensing number in a mortgage deed as evidence of its nonenforceability. ${ }^{176}$

We favor a national regulatory system enacted by Congress. The Financial Stability Oversight Council (FSOC) may recommend the licensing scheme to the existing banking and financial regulators under its power to "identify gaps in regulation that could pose risks to the financial stability of the United States," mortgage origination. Similarly, the Consumer Financial Protection Bureau lacks authority to institute this system because 12 U.S.C. $\S 5511$ specifically enumerates its powers, which do not include imposing a licensing requirement on mortgage lending. Accordingly, statutory reform is necessary to implement the licensing regime. ${ }^{178}$

173. See, e.g., 15 U.S.C. $\S 1604$ (2012) (mandating certain disclosures for mortgage loan transactions); 15 C.F.R. $\S 226$ (2013) (implementing the disclosure requirements of the Truth in Lending Act, 15 U.S.C. $\$ \S 1601-1667$ (2012)).

174. The identity of license holders and the number of licenses in use would be public, but the identity of specific housing transactions using the license would be non-public to preserve homeowner privacy about the specifics of their finances.

175. See discussion infra notes 189-190 and accompanying text.

176. Of course, this raises issues with the transition period. Third parties would presumably be aware that the licensing requirement applies only to loans issued after a certain date, such that the absence of a valid license number on a deed prior to that date would not have any legal implications.

177. 12 U.S.C. $\$ 5322(a)(2)(G)(2012)$.

178. This raises a question of whether the licensing regime restraining the ability of actors to engage in ordinary contracting oversteps the reach of congressional power under the Commerce Clause. In many cases, no constitutional problem would arise with a federal approach 
The notion of requiring licenses at the point of mortgage origination could lead to an objection that licensing would be more effective if imposed at the point of securitization. Since securitization in the secondary market drives the demand for mortgage origination, it might be possible to impose the licensing requirement upon securitizers. Nonetheless, there are several practical problems with imposing the licensing requirement at the securitization level. It is the actual act of initiating-originating-the mortgage loan that shapes the distribution of equity in a given region or nationwide. Imposing a requirement that securitizers obtain a license before purchasing a loan from an originator would simply raise the cost of securitization and thus merely encourage originators to hold rather than securitize such loans. This would not substantially affect systemic stability because non-securitized loans could still be offered at any equity level. Moreover, it would be much more difficult for regulators to evaluate whether a given loan was properly licensed because the derivative securities created from one mortgage may be repackaged and widely dispersed among investors. More generally, regulating the resale of a mortgage is far more difficult than restricting the original transaction that initiated the loan.

\section{Setting the Size of the Caps and Defining the Jurisdictions}

To implement a licensing system, it is necessary to tailor several dimensions of the licenses. The foregoing example imagined specific leverage ranges and arbitrarily set the number of licenses as a proportion of the number of residential homes. However, there is nothing magical about either the specific leverage ranges or the cap sizes laid out above in Table 10. Regulators would ideally set the number of licenses for particular leverage ranges by considering the risk of particular price downturns, the likelihood that a price downturn would induce mortgage defaults, and the ability of the market to absorb defaults if affected homes in a particular equity range were unleashed on the market by foreclosure sales. In setting the number of licenses for different levels of leverage, regulators should trade off the macroeconomic benefits of

because many loans are originated across state lines. Yet even for mortgages that originate entirely within one state, the Commerce Clause, even after Lopez and its progeny, is unlikely to prevent a federal licensing requirement. United States v. Lopez, 514 U.S. 549 (1995). Though the fundamental legal instrument in question-secured liens - is a product of state law, even purely intrastate mortgage transactions may affect the interstate housing market. Indeed, federal truth-in-lending law and HMDA regulations have routinely been upheld as appropriate uses of federal power, and the ongoing financial crisis vividly demonstrates that housing instability in individual states can produce nationwide impacts. Alternatively, compliance with the licensing regime might be implemented as a condition for receiving federal benefits of some kind such as registration as a federal bank or even participation in an interstate market. For example, Congress could mandate that mortgage securities may not be sold across state lines unless the underlying mortgages are licensed as required by the licensing regime. If all else fails, Congress might institute a penalty for holding a noncompliant mortgage, akin to the Affordable Care Act's individual responsibility penalty recently upheld by the Court under the Taxing Power. See Nat'1 Fed. of Indep. Bus. v. Sebelius, 132 S. Ct. 2566, 2594 (2012). 
fewer licenses with the microeconomic costs on affected homeowners. The foregoing caps imagined a monotonically increasing number of licenses for higher levels of equity, but regulators might also consider a "circuit breaker" approach that issued fewer licenses for intermediate levels of leverage. ${ }^{179}$

The number of outstanding licenses can also be updated by ongoing regulatory interventions in the licensing market. Regulators could issue additional licenses when they saw untoward shortages that unduly impeded transactions that would not undermine market stability. Or regulators who feared that the housing market was becoming overheated might limit highleverage speculation by buying back certain licenses in open market transactions. Robert Shiller has analogously suggested increasing the leverage requirements for buying stock on margin when $\mathrm{P} / \mathrm{E}$ ratios suggest increased risk of a stock bubble. ${ }^{180}$ Regulators who see the price/rental ratio increasing might similarly intervene to reduce the number of leverage licenses.

The licensing framework should thus include an equity monitoring component that would require mortgage servicers to report both the outstanding principal balance remaining as well as the estimated current value of the home-using Zillow-like automated appraisal technology based on comparable sales. Once the technology was implemented, regulators could quickly obtain a workable estimate about the distribution of homeowners' equity-based not just on the outstanding licenses but on the amount of equity on the ground, which can be impacted by prepayments and changes in pricing values. Aggregate information on the distribution of equity can importantly inform regulators' decisions on whether and how to intervene in the licensing market.

A license system would also need to define the geographic area over which particular licenses could be used. An important goal would be to define the areas with an eye toward the amounts of probable default that particular markets could tolerate. Presumptively, tailoring the license coverage to broad areas in which houses broadly compete on price and other factors would capture the impact of foreclosure-induced selling on housing prices. Defining the geographic market too broadly (say, at the national level) would allow a cluster of highly leveraged homes in a particular local market that might unnecessarily set up that market for economic dislocation. And the recent crisis has shown that dislocation in specific states might result in untoward national impacts. Accordingly, we think that licenses should at least be limited to

179. For example, an equilibrium with relatively few mortgages with equity between, say, $3 \%$ and $6 \%$ might provide a circuit breaker to impede a $5 \%$ downturn in pricing from inducing a cascade of successive defaults and price downturns.

180. Robert J. Shiller, Margin Calls: Should the Fed Step In?-Yes, It May Avert Disaster, WALL ST. J., Apr. 10, 2000, http://cowles.econ.yale.edu/news/shiller/rjs_00-04-10_wsj_margin .htm. 
particular states and might even be limited to Metropolitan Statistical Areas (MSAs). ${ }^{181}$

Examining the distribution of equity at the local, state, or regional level might enable regulators to better respond to cultural, demographic, and other socioeconomic differences between borrowers in different regions. Some regions, for example, might view negative equity-induced default as morally wrong, suggesting that low-equity clustering might be less of a concern. Ongoing adjustment of the license quantities would also allow regulators to respond to mal-distributions of equity in particular areas. For example, in the first quarter of 2011 , the eleven states analyzed above exhibited the following distribution of equity in their residential homes ${ }^{182}$ :

181. Metropolitan Statistical Areas are "geographic entities delineated by the Office of Management and Budget (OMB) for use by Federal statistical agencies in collecting, tabulating, and publishing Federal statistics." Metropolitan and Micropolitan Statistical Areas Main, U.S. CENSUS BUREAU, http://www.census.gov/population/metro (last visited Feb. 14, 2014).

182. The source of this data is described in our online appendix to this Article. Ian Ayres \& Joshua Mitts, Online Appendix to Three Proposals for Regulating the Distribution of Home Equity (2013), http://islandia.law.yale.edu/ayres/onlineappendix.pdf. 
The Distribution of Home Equity

Table 11: Distribution of Equity in 2011q1

\begin{tabular}{l|rrrrrrrrr}
\hline State & $<\mathbf{0} \%$ & $\mathbf{0 - 3} \%$ & $\mathbf{3 - 6 \%}$ & $\mathbf{6 - 9} \%$ & $\mathbf{9 - 1 2 \%}$ & $\mathbf{1 2 - 1 5 \%}$ & $\mathbf{1 5 - 2 0 \%}$ & $\mathbf{2 0 - 5 0 \%}$ & $\mathbf{5 0 - 1 0 0 \%}$ \\
\hline AZ & $36 \%$ & $0 \%$ & $0 \%$ & $0 \%$ & $2 \%$ & $0 \%$ & $8 \%$ & $25 \%$ & $29 \%$ \\
CA & $13 \%$ & $3 \%$ & $1 \%$ & $2 \%$ & $2 \%$ & $3 \%$ & $2 \%$ & $20 \%$ & $54 \%$ \\
FL & $18 \%$ & $1 \%$ & $2 \%$ & $2 \%$ & $1 \%$ & $4 \%$ & $2 \%$ & $24 \%$ & $45 \%$ \\
IL & $15 \%$ & $4 \%$ & $2 \%$ & $4 \%$ & $4 \%$ & $1 \%$ & $2 \%$ & $25 \%$ & $44 \%$ \\
MI & $26 \%$ & $3 \%$ & $6 \%$ & $5 \%$ & $3 \%$ & $5 \%$ & $6 \%$ & $14 \%$ & $31 \%$ \\
NJ & $7 \%$ & $1 \%$ & $0 \%$ & $0 \%$ & $4 \%$ & $4 \%$ & $5 \%$ & $16 \%$ & $64 \%$ \\
NV & $57 \%$ & $0 \%$ & $0 \%$ & $0 \%$ & $4 \%$ & $0 \%$ & $4 \%$ & $7 \%$ & $29 \%$ \\
NY & $9 \%$ & $0 \%$ & $1 \%$ & $3 \%$ & $1 \%$ & $0 \%$ & $4 \%$ & $24 \%$ & $58 \%$ \\
OH & $15 \%$ & $2 \%$ & $3 \%$ & $5 \%$ & $3 \%$ & $0 \%$ & $0 \%$ & $28 \%$ & $44 \%$ \\
PA & $7 \%$ & $0 \%$ & $1 \%$ & $1 \%$ & $5 \%$ & $2 \%$ & $7 \%$ & $35 \%$ & $42 \%$ \\
TX & $10 \%$ & $5 \%$ & $4 \%$ & $6 \%$ & $4 \%$ & $4 \%$ & $4 \%$ & $28 \%$ & $35 \%$ \\
\hline
\end{tabular}

Note the wide disparities in the proportion of houses with negative equity. More than half of Nevada homes (and more than a third of Arizona homes) were financially underwater, whereas only $7 \%$ of New Jersey and Pennsylvania homes were in this kind of distress. Regulators might respond by issuing fewer leverage licenses in distressed areas (or possibly by allowing temporary licensing exemptions for transactions that replaced negative equity mortgages with modified mortgages that were less likely to default).

Moreover, the cascading effect of default and falling prices might be much more pronounced at a neighborhood level, suggesting that regulating the distribution of equity at even the sub-MSA level might be most effective in combatting the potential consequences of low-equity clustering. More localized licenses might also allow regulators to respond to the impact of licensing on minorities and lower-income borrowers. Indeed, a key distinction between our proposal and the QRM $20 \%$ minimum down payment is that under ours, lowerequity licenses could be issued selectively to benefit creditworthy borrowers who lack sufficient capital to put more money down.

For example, regulators might create a still limited, but expanded, number of licenses for houses located in the existing list of communities identified as in need of assistance under the Community Reinvestment Act (CRA). ${ }^{183}$ The primary purpose of the CRA is to ensure that depository institutions meet the needs of their local communities, and criteria have been identified by the federal agencies implementing the CRA to determine urban areas that are

183. See generally 12 U.S.C. $\S 2901$ (2012); Community Reinvestment Act: Background \& Purpose, FED. FIN. INST. EXAMINATION COUNCIL, http://www.ffiec.gov/cra/history.htm (last visited Feb. 14, 2014) ("The Community Reinvestment Act is intended to encourage depository institutions to help meet the credit needs of the communities in which they operate, including low- and moderate-income neighborhoods, consistent with safe and sound banking operations."). 
considered underserved. ${ }^{184}$ For nonmetropolitan areas, the agencies may analogously establish licenses for individual regions that are distressed or underserved. ${ }^{185}$ For example, the category of distressed regions includes those affected by poverty, unemployment, or substantial population loss. ${ }^{186}$ The category of underserved regions includes remote rural locations. ${ }^{187}$ The agencies also track whether a region was designated as distressed or underserved in the prior year. ${ }^{188}$ These categories could serve as useful criteria for establishing the number of area-specific licenses to balance the tension between enhancing macroeconomic stability and making the dream of homeownership available to creditworthy minorities and lower-income borrowers who may lack the wealth to produce a large initial down payment. ${ }^{189}$

\section{Transition and Enforcement}

In steady state, one can easily imagine a system in which the license regulator would periodically auction licenses for specific geographic areas, specific equity percentages, and specific years. As a practical matter lenders would not need licenses for more than thirty years in advance (and for amortizing loans originators would not need to secure licenses for more than fifteen years in advance). Any investor might purchase a license in contemplation of reselling in the future to an originator at reasonable degrees of amortization. But difficult questions arise about how to transition to this regime in a world where a large stock of homeowners will exist at the time of adoption who previously financed their homes without leverage licenses. One transition approach would issue free-of-charge licenses for all existing mortgages for current and future years according to the individual homeowner's current amount of equity and scheduled repayments. An advantage of such a one-time

184. See, e.g., FFIEC Census Information Sheets, FED. FIN. INST. EXAMINATION COUNCIL, http://www.ffiec.gov/census/censusInfo.aspx (last visited Feb. 14, 2014) (describing the census criteria employed by regulators when implementing depository institutions' obligations under the CRA).

185. E.g., 2011 List of Middle-Income Nonmetropolitan Distressed or Underserved Geographies, FED. FIN. INST. EXAMINATION COUNCIL (2011), http://www.ffiec.gov/cra/pdf/201 ldistress edorunderservedtracts.pdf.

186. For a detailed description of the methodology employed to calculate these categories, see 2011 Distressed or Underserved Nonmetropolitan Middle-Income Geographies Source Information and Methodology, FED. FIN. INST. EXAMINATION COUNCIL (2011), http://www.ffiec.gov/cra /pdf/sourcelist2011.pdf.

187. See id.

188. See FED. FIN. INST. EXAMINATION COUNCIL, supra note 185.

189. That said, regulators should take care to ensure that a policy of directing lowequity licenses to underserved borrowers does not lead to geographic "pockets" of low-equity mortgages. See, e.g., Meribah Knight \& Bridget O'Shea, Foreclosures Leave Pockets of Neglect and Decay, N.Y. TIMES, Oct. 27, 2011, http://www.nytimes.com/2011/10/28/us/foreclosures-lead-to-crime-a nd-decay-in-abandoned-buildings.html. Of course, one does not necessarily follow from the other: regulators can favor needy communities while still spreading out these low-equity licenses and ensuring that geographic regions retain a sufficiently diverse distribution of equity. 
distribution is that it would give existing homeowners with high leverage an economic incentive to reduce their leverage. This is because a homeowner with a high-leverage mortgage could resell licenses granted for future years by refinancing the loan on less leveraged terms. For states like Arizona where the existing stock of negative equity mortgages radically exceeds the prudent level, agency offers to buy back licenses that were distributed to existing homeowners would provide an additional mechanism to incentivize homeowners to modify and refinance their homes in ways that reduced systemic market risk.

The question of how to enforce the licensing regime is particularly tricky. The most traditional approach would simply impose penalties and sanctions for noncompliance. Such a system might render the licensing system effective with respect to large banks and institutional lenders who would likely comply, but could have the unintended consequence of driving lending activity "underground" and further out of regulatory oversight. This would require a policing apparatus, which might be quite expensive because of the localized nature of mortgage lending. Moreover, it is unclear who would be subject to such top-down enforcement. As mortgage documents are typically presented to consumers by mortgage brokers, brokers would be a natural target for compliance with the licensing requirement. However, there are hundreds of thousands of mortgage brokers, possibly making the cost of enforcement prohibitively high. ${ }^{190}$ Enforcing the licensing regime among loan originators might be much cheaper, but could lead to customers signing unlicensed mortgage documents and brokers merely relying on compliance at the point of loan origination.

An alternative approach that might be more cost-effective is to utilize a system of private enforcement by rendering the mortgage lien unenforceable and the associated loan agreement voidable for unlicensed mortgages. This would provide lenders with a strong incentive for compliance with the licensing regime, and shift the burden of policing compliance to borrowers. However, the prospect of unenforceability might lead to a dramatic increase in litigation as borrowers facing foreclosure attempted to show that the mortgage was unlicensed. These higher litigation costs would likely be passed on to borrowers in the form of higher interest rates or reduced lending. Moreover, enacting the unenforceability provisions at the state level might be extremely difficult to accomplish as a practical matter. Any nonconforming states would quickly become a haven for lenders seeking to escape the licensing burden,

190. See John Gittelsohn, U.S. Mortgage Brokers Get Criminal Check, Tests Under New Rules, BLOOMBERG (July 21, 2010, 9:40 AM), http://www.bloomberg.com/news/2010-0721/mortgage-brokers-get-criminal-checks-with-new-u-s-rules-to-cut-loan-fraud.html (listing the total number of mortgage brokers nationwide as 246,900 as of May 2010). 
possibly rendering it impotent as a mechanism to regulate the market as a whole. $^{191}$

\section{B. Varying Conforming Mortgages for Fannie Mae and Freddie Mac}

In this Section, we propose an alternative approach to regulating the distribution of home equity that does not require the type of sweeping statutory reform that would be necessary to implement the licensing scheme. The "GSEs"- "Fannie Mae" and "Freddie Mac"-perform a central role in the U.S. mortgage market. Instituting a new paradigm of variation into the definition of "conforming mortgage" utilized by the GSEs would permit regulating the distribution of home equity without directly restricting private contracting. This proposal would give the GSEs an important role in preserving macroprudential financial stability while only requiring minimal statutory reform.

\section{The Role of the GSEs in the U.S. Mortgage Market}

Fannie Mae and Freddie Mac fulfill an important role in the mortgage market by purchasing and guaranteeing mortgages that are not insured or guaranteed directly by the U.S. government. While government-insured loans such as the FHA mortgages discussed in Subsection III.A.2 are attractive to borrowers because their availability does not depend on macroeconomic credit conditions, this explicit government guarantee comes at a price: the Department of Housing and Urban Development imposes a surcharge on FHA loans in the form of an up-front and annual mortgage insurance premium of $1.75 \%$ and $0.35-1.5 \%$ of the base loan amount, respectively. ${ }^{192}$ In the absence of extraordinary market conditions, this surcharge renders government-backed loans more expensive for borrowers than mortgages obtained in the private market.

Even though private mortgages lack this surcharge for borrowers, private lenders are likely to impose more stringent underwriting criteria or higher interest rates than the FHA in the absence of any additional government support because they lack an incentive to internalize the social benefit of widespread homeownership. Accordingly, if the mortgage market consisted solely of private lenders and government-insured loans, many creditworthy borrowers who failed to qualify at reasonable rates under stringent self-interested private lending criteria would be forced to obtain a mortgage through the governmentinsured programs with high fixed surcharges that were unnecessary in light of these borrowers' relatively low credit risk. The GSEs step into this gap by

191. On the other hand, a regional approach might still work within those states that are

192. Single Family Mortgage Insurance: Annual and Up-Front Mortgage Insurance Premium-Changes, U.S. DEP'T OF HOUS. \& URB. DEV. (Mar. 6, 2012), http://portal.hud.gov/hudportal /documents/huddoc?id=1204ml.pdf. 
purchasing, guaranteeing, and repackaging private loans into mortgage-backed securities that are resold on the secondary market to investors. This provides crucial liquidity and effectively functions as a partial subsidy for originating mortgages to the vast majority of borrowers whose credit profiles would justify reasonable interest rates without the surcharge accompanying explicit government-insured loans.

Fannie Mae and Freddie Mac offer to buy a variety of specific "products"-i.e., mortgages with acceptable terms--that reflect market conditions and borrower demand. ${ }^{193}$ But the GSEs are governed by a statutory framework that permits only the acquisition of so-called "conforming mortgages." "194 The notion of a conforming mortgage is defined in each GSE's enabling statute as a "conventional mortgage"-i.e., one not guaranteed by the federal government-that meets a series of requirements, including maximum principal limits and a prohibition on "the outstanding principal balance of the mortgage at the time of purchase exceed[ing] 80 per centum of the value of the property securing the mortgage." 195 However, the statute provides an exception to the latter requirement: the GSEs may acquire loans with an excess of $80 \%$ LTV if "that portion of the unpaid principal balance of the mortgage which is in excess of such 80 per centum is guaranteed or insured by a qualified insurer as determined by the [applicable GSE]." 196 The requirement to purchase private mortgage insurance thus somewhat offsets the benefit of GSE involvement in the mortgage markets for loans with an LTV greater than $80 \% .{ }^{197}$

The vast majority of mortgage lenders follow the GSE guidelines because mortgage-backed securities packaged and resold by Fannie Mae and Freddie Mac virtually dominate the secondary markets along with those from Ginnie Mae, which resells government-insured loans. ${ }^{198}$ This is likely a result of the

193. See, e.g., Single-Family: Mortgage Products, FANNIE MAE, http://www fanniemae.com/singlefamily/mortgage-products (last visited Feb. 14, 2014); Doing Business With Freddie Mac, FREDDIE MAC, http://www.freddiemac.com/corporate/doing_business.html (last visited Feb. 14, 2014).

194. 12 U.S.C. $\S 4502(26)$ (2012) (defining a "conforming mortgage" as "a conventional mortgage having an original principal obligation that does not exceed the dollar amount limitation in effect at the time of such origination and applicable to such mortgage" under the GSEs" enabling statutes). The term "conforming mortgage" was added by the Housing and Economic Recovery Act of 2008, and is not utilized in the GSE statutes, but simply reflects the substantive requirements for GSE acquisition of loans as found in those statutes.

195. Id. $\S 1717(\mathrm{~b})(2)$ (imposing this limitation on Fannie Mae); id. $\S 1454(\mathrm{a})(2)$ (imposing identical limitation on Freddie Mac).

196. Id. $\S 1717(\mathrm{~b})(2)$.

197. Indeed, with high LTV ratios, private mortgage insurance may be so expensive that an FHA loan is cheaper for borrowers.

198. See MBS Live: MBS Dashboard, MoRTGage NEwS DaILY, http://www.mortgagenewsdaily.com/mbs (last visited Feb. 14, 2014); Mortgage-Backed Securities ETF (VMBS): Portfolio, VANGUARD, http://institutional.vanguard.com/VGApp/iip/site/institutional/investme nts/portfoliodetails?fundId $=3148$ \#state $=90$ (last visited Feb. 14, 2014) (mortgage-backed securities exchange-traded fund consisting entirely of Fannie Mae, Freddie Mac, or Ginnie Mae mortgage-backed securities). 
government guarantee that the GSEs enjoy after being subjected to FHFA conservatorship in $2008,{ }^{199}$ which renders private competition largely futile. Accordingly, the statutory guidelines for lending limits and LTV ratios for the GSEs largely determine the contours of the conventional mortgage market similar to FHA's requirements for government-insured loans.

The key point in light of the analysis in this Article is that the regulatory paradigm reflected in both the GSEs' and FHA's approach to minimum down payments/LTV ratios consists of a binary, on/off approach to encouraging or discouraging risky loans that does not consider the negative social externality of an excessive concentration of mortgages at low levels of equity. As discussed previously in Subsection III.A.2, the FHA's $3.5 \%$ minimum down payment requirement directly facilitates low-equity clustering. But the GSE guidelines, which determine the vast majority of the mortgage market, also fail to take into account the systemic implications of a binary, conforming/nonconforming approach to mortgage origination. The GSE statute imposes increasing costs for lower down payments solely by requiring private mortgage insurance. But private insurers do not necessarily internalize the social cost of excessive low-equity clustering. High LTV loans might be marginally more expensive than those with a greater down payment-whether because of the FHA surcharge or the private mortgage insurance for a conventional loan - but that does not ensure that equity levels among borrowers are distributed in a manner that reduces the systemic risk from simultaneous exposure to negative equity and cascading foreclosures.

For example, if the cost of private insurance for a $7 \%$ down payment loan were sufficiently low, the vast majority of borrowers might cluster at that level even if it was slightly more expensive than a $20 \%$ down payment. And if both private mortgage insurance and the FHA surcharge were so expensive as to render any loan with an LTV greater than $80 \%$ extraordinarily expensive, the distributional concerns we raised regarding the Dodd-Frank QRM proposal would apply with equal force. The problem is the paradigm: permitting or prohibiting specific mortgage terms in a binary manner-e.g., with a conforming/nonconforming distinction or flat minimum down payment of $3.5 \%$ (FHA loans) or 20\% (QRM proposal) - can lead to excessive clustering that imposes greater systemic risk. Accordingly, as an alternative way to regulate the distribution of home equity that is more implementable than our licensing proposal, we suggest that Congress adopt a system of varying conformity for mortgages purchased or guaranteed by the GSEs as described in the next Subsection.

199. See Glenn Somerville, U.S. Seizes Fannie, Freddie, Aims to Calm Markets, REUTERS (Sept. 7, 2008, 7:25 PM), http://www.reuters.com/article/2008/09/07/us-fannie-freddie-idUSN 0527106320080907 . 


\section{A New Paradigm of Variation in Conforming Mortgages}

As a starting point for this proposal, we suggest that the legislative reform necessary to bring the GSEs out of conservatorship consider not merely how to prevent their failure but also what roles these institutions can play in reducing systemic risk in the mortgage market. Fannie Mae and Freddie Mac are uniquely positioned to induce beneficial diversity in the distribution of home equity because they dictate the terms under which mortgages are resold, packaged, and distributed in mortgage-backed securities. Indeed, their implicit government guarantee practically guarantees a monopoly on the MBS secondary markets, suggesting that they would be well suited to influence the entirety of national mortgage originations.

We propose redefining the "conforming mortgages" restriction on the GSEs' activity to incorporate varying degrees of conformity. The GSEs should have discretion to offer different prices for different levels of conformity, under the guiding principle of reducing systemic risk by inducing an appropriate distribution of equity. This would empower the GSEs to incentivize beneficially varying conformity by simply setting the price they are willing to offer for mortgage products at each level. Interestingly, a varying conformity approach would permit more fine-tuned control than our licensing scheme: in addition to regulating the equity level of each loan, the GSEs could set separate prices for different characteristics-such as adjustable-rate vs. fixed-rate or fully amortizing vs. balloon payment loans-to obtain more granular control over the distribution of terms that affect homeowners' accumulation of equity.

The "price" for each level of conformity should be a premium on the base discount rate offered by the GSEs to lenders. The benchmark rate for acquisitions of mortgages by the GSEs, known as the "commitment rate," is typically set by Fannie Mae for different delivery durations. The most common rate is the 30-year fixed rate for delivery within 60 days, ${ }^{200}$ which ranged from $3.86 \%-4.40 \%$ in September $2013 .{ }^{201}$ While this rate would vary for individual products according to Fannie Mae and Freddie Mac's "live pricing,"202 we propose adding a nonconformity premium to the base rate that individual product-specific prices are constructed from. This nonconformity premium could adjust over time to ensure that the social cost of excessive clustering at

200. See FNMA 30-Yr Mtg Com Del 60 Days, BANKRATE.COM, http://www.bankrate.co $\mathrm{m} /$ rates/interest-rates/fannie-mae-30-year-mtg-com-del-60-days.aspx (last visited Feb. 14, 2014).

201. Mandatory Delivery Commitment - 30-Year Fixed Rate A/A, FANNIE MAE, https://www.fanniemae.com/content/datagrid/hist_net_yields/sep30.html (last visited Sept. 30, 2013). The current "commitment rate" is available online. Mandatory Delivery Commitment - 30-Year Fixed Rate $A / A$, FANNIE MAE, https://www.fanniemae.com/content/datagrid/hist_net_yields/cur30.html (last visited Feb. 14, 2014).

202. See, e.g., Selling Whole Loans to Fannie Mae, FannIE MAE 30 (2012), https://www.fanniemae.com/content/job_aid/selling-whole-loans.pdf. 
certain levels of conformity would be internalized by lenders and borrowers regardless of the specific pricing for each product.

To account for differing regional distributions of equity the GSEs could vary the premium by the geographic area where the home is physically located. And as noted previously, these nonconformity premia might also be conditioned on other volatility-inducing mortgage terms discussed above (such as balloons and interest resets) to cap their prevalence in the market. The GSEs could even extend this pricing system to incorporate borrowers' credit scores. For example, the GSEs could discount a small number of high-equity loans made to low-scoring borrowers alongside low-equity loans to high-scoring borrowers, but impose a high premium on low-equity loans to low-scoring borrowers.

A key difference between the licensing system and this varying conformity proposal is that licenses would apply annually, thus automatically updating in "real-time" in response to changing equity levels and eliminating the need to forecast the impact of a given set of mortgage terms on equity accumulation over the life of the loan. However, Fannie Mae and Freddie Mac purchase loans from originators at a single point in time, so there is no practical way for this price to vary with the actual accumulation of equity over time. Accordingly, the premium set by the GSEs should reflect a forecast of the propensity for each loan to contribute to equity accumulation, akin to how the NBA salary cap takes into account the impact of players' salaries on future revenues. $^{203}$

While such a forecast would necessarily be imperfect, the GSEs could utilize a "probability" of equity accumulation based on the presence or absence of specific terms in the loan. For example, a fully amortizing 30-year fixed-rate mortgage could serve as the benchmark with a probability of equity accumulation equal to 1 , and other terms-such as adjustable rates or balloon payments-would decrease this probability. A probability less than 1 would increase the premium for that specific type of mortgage product. This is precisely where the granularity of the varying conformity approach is beneficial: the GSEs could vary the premium for each combination of down payments and terms based on the loan's forecasted propensity to contribute to low-equity clustering.

Of course, as with the licensing scheme, the GSEs will require a continual stream of data reporting to monitor the distribution of equity in each geographic region and adjust the premium pricing accordingly. Another implementation advantage of this varying conformity approach is that GSEs are contractual counterparties to mortgage originators and thus could require, as a condition of purchasing the loan, that any mortgage servicer transmit periodic reports of

203. See Larry Coon, 2011 Collective Bargaining Agreement, LARRY COON'S NBA SALARY CAP FAQ, http://www.cbafaq.com/salarycap.htm (last visited Feb. 14, 2014). 
principal balances to the GSEs. The GSEs could then use this data, along with Zillow-like property appraisal technology, ${ }^{204}$ to compute and monitor an approximate equity level for each loan purchased and repackaged in mortgagebacked securities. The GSEs already maintain loan-level data to service payments to MBS holders, so this should not be particularly difficult to implement.

Finally, unlike the licensing system, the varying conformity approach would require minimal statutory reform. Congress would simply (1) broaden the GSEs' statutory responsibilities to include monitoring the distribution of regional equity levels among the mortgages they hold, and (2) modify the "conforming mortgage" definition to compel the GSEs to apply a down payment and term-specific premium to the commitment rate that would discourage excessive clustering at low levels of equity. Unlike the licensing scheme, this approach would not impose conditions on private contracting. In light of the minimal statutory changes that would be required, we recommend that Congress adopt this proposal when it considers reforming the GSEs as they emerge from conservatorship.

\section{Conclusion}

The traditional story about what caused the Great Recession is simply that the housing bubble popped. Robert Shiller was right to point out that the postmillennial upward spike in housing prices witnessed in city after city could not be sustained. ${ }^{205}$ When the bubble popped, many homeowners, who found themselves with mortgage obligations substantially larger than the cratering equity values in their homes, chose or were forced to default. These defaults in turn wreaked havoc on financial institutions that held securitized pools of these mortgages or derivative bets on these pools.

The bubble story continues to be compelling. But this Article argues that the impact of the popping bubble was likely exacerbated by the contractual terms included in hundreds of thousands of mortgages. In sharp contrast to what we have called the amortization era, when successive cohorts of homeowners would start with larger down payments and smoothly add to their equity over time, our nation entered the housing crisis with a stock of mortgage terms that left our housing and mortgage markets more sensitive to price fluctuations and susceptible to default. A central claim of this Article is that the microeconomics of contracting can have macroeconomic impacts. Specifically, we have tried to show that systemic risk was artificially inflated by the increased prevalence of four particular mortgage terms that increased the chance either that borrowers would default or that borrowers would be unable

204. Zillow.com uses data on recent sales to estimate the value of real estate.

205. See, e.g., David Leonhardt, Be Warned: Mr. Bubble's Worried Again, N.Y. TIMES, Aug. 21, 2005, http://www.nytimes.com/2005/08/21/business/yourmoney/21 real.html. 
to refinance a mortgage that they could no longer pay. When combined with the dramatic increase in cash-out refinancing, the independent borrowing decisions of millions of Americans left us with a distribution of housing equity that was more likely to induce a destabilizing cascade of defaults, which in all likelihood further depressed housing prices.

We have proposed three different ways that regulators might move us back toward the beneficial equity dispersion that was a natural byproduct of the amortization era. Our modified home mortgage interest deduction incentivizes homeowners to opt for repayment terms that are more likely to accrue equity over time (and less likely to require interim refinancing). Our modified risk retention rules incentivize lenders to make analogous amortizing loans and discourages the equity-stripping of cash-out refinancing. Finally, our leverage licensing proposal is a "cap and trade" intervention, which directly regulates the distribution of equity by limiting the maximum amount of various levels of equity, and our suggestion to introduce varying conforming mortgages for Fannie Mae and Freddie Mac is a more implementable alternative that does not require extensive statutory reform.

These proposals might be adopted individually or in combination. But our larger normative claim is that regulators should care not just about the average homeowner equity in the system, but also about how the equity is dispersed. The recent crisis shows that large clusters of homeowners with low equity can be dangerous. Housing and mortgage markets would be safer if different homeowners had different amounts of equity so that housing price fluctuations would be less likely to induce mass waves of default.

While this Article has focused on the distribution of leverage in mortgages, our analysis also suggests that the law should look to induce nonuniform leverage in other financial settings. In particular, our analysis suggests that an economy might be less exposed to systemic risk if banks (and other financial intermediaries) had different leverage levels. If all banks in an economy are clustered at low levels of equity, then a uniform drop in the value of their assets might analogously cause a synchronized set of bank defaults that might be more disruptive than would occur with less clustered leverage levels. Thus, while market competition might induce individual actors to pool toward similar, socially deleterious levels of leverage, regulators should look to policies that instead seek to induce separating leverage equilibria. Instead of clinging to a norm of equal treatment under the law, our analysis identifies circumstances where regulatory variances and licenses might be used to induce beneficial diversity. ${ }^{206}$

206. See Ian Ayres \& John Braithwaite, Partial-Industry Regulation: A Monopsony Standard for Consumer Protection, 80 CAL. L. REv. 13, 15-16 (1992) (discussing the notion of beneficial diversity in the regulatory context). 